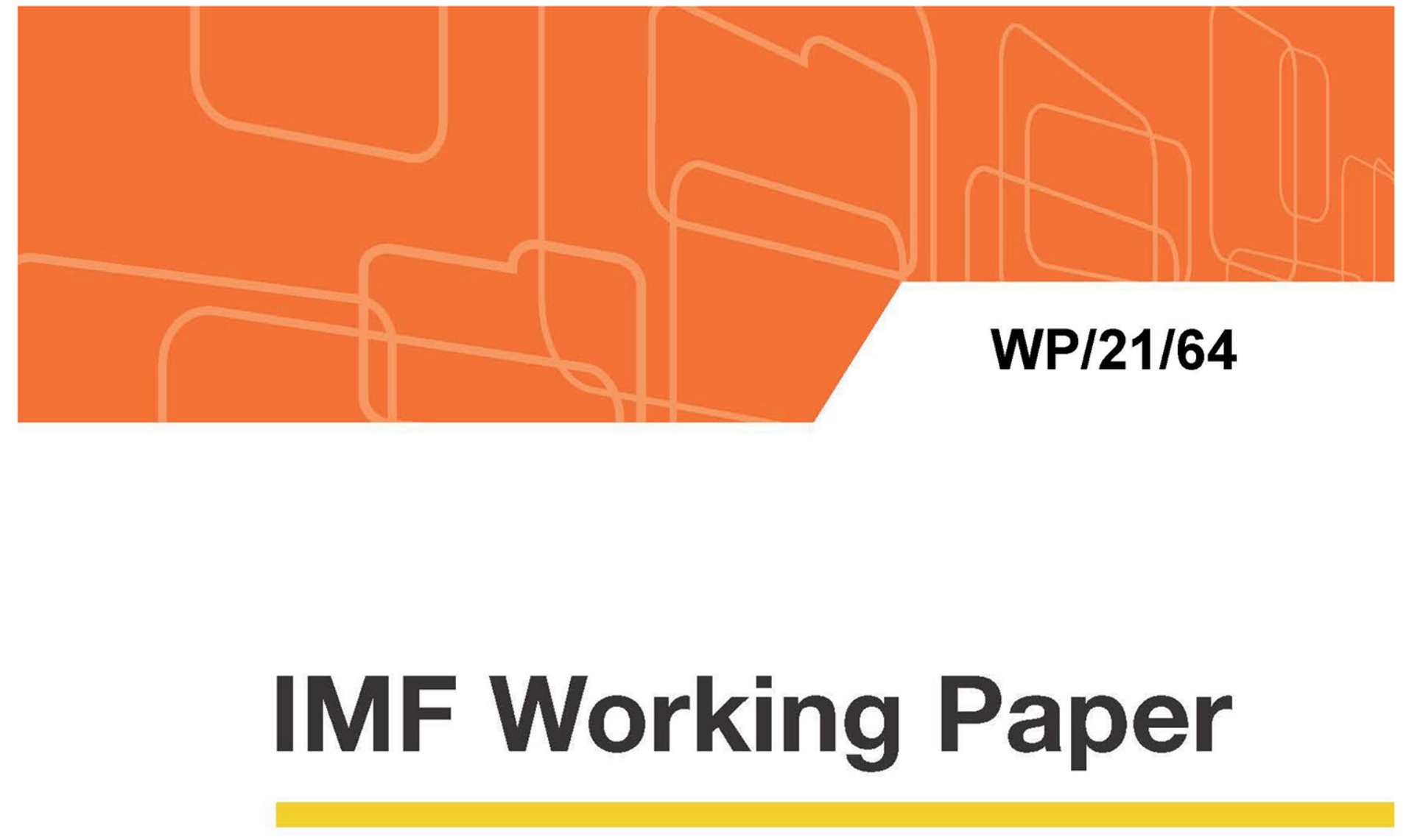

\title{
Proximity and Horizontal Policies: The Backbone of Export Diversification and Complexity
}

\author{
by Gonzalo Salinas
}

IMF Working Papers describe research in progress by the author(s) and are published to elicit comments and to encourage debate. The views expressed in IMF Working Papers are those of the author(s) and do not necessarily represent the views of the IMF, its Executive Board, or IMF management.

$$
\text { I N T E R N A T I O N A L M O N E T A R Y F U N D }
$$




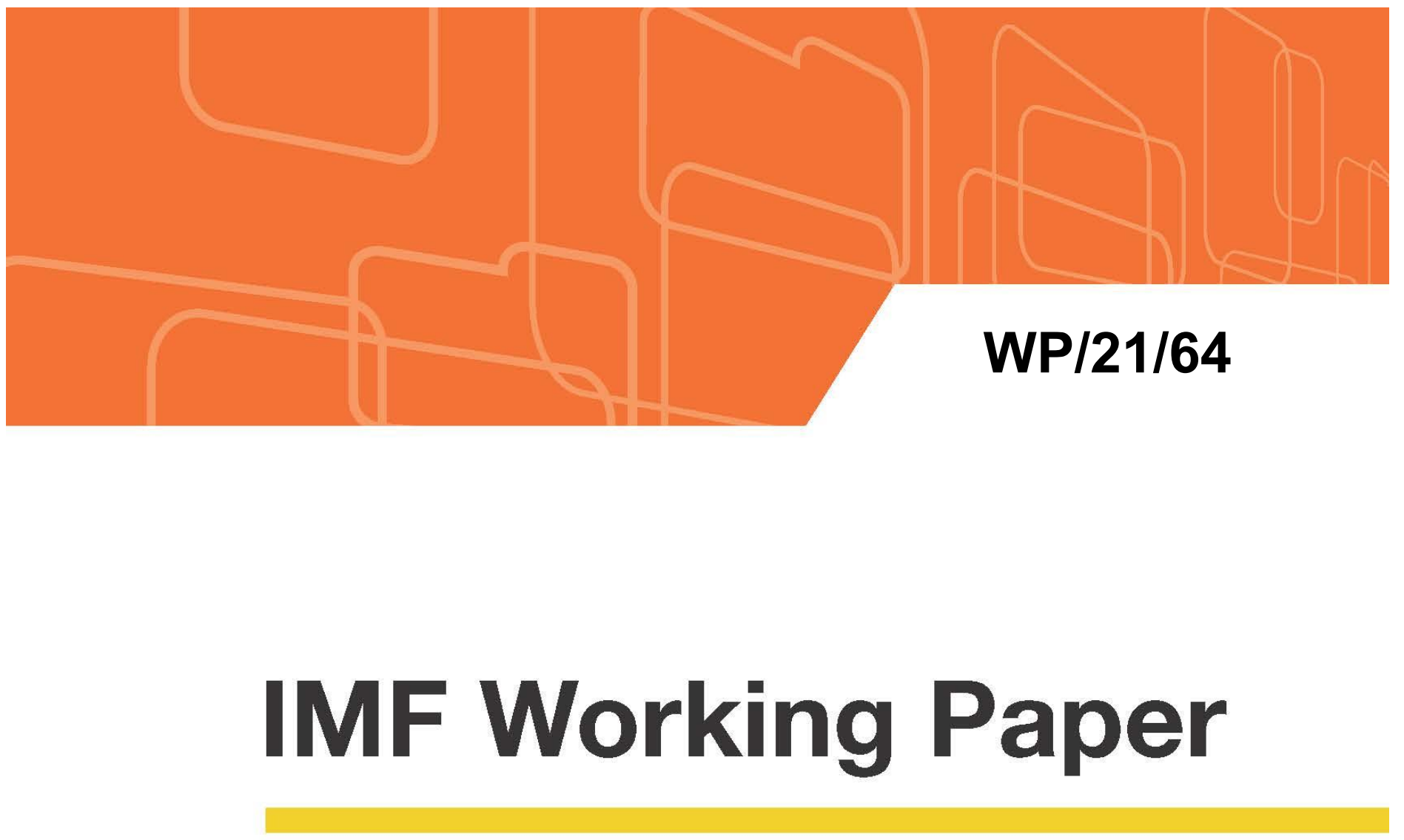

\title{
Proximity and Horizontal Policies: The Backbone of Export Diversification and Complexity
}

\author{
by Gonzalo Salinas
}

IMF Working Papers describe research in progress by the author(s) and are published to elicit comments and to encourage debate. The views expressed in IMF Working Papers are those of the author(s) and do not necessarily represent the views of the IMF, its Executive Board, or IMF management.

$$
\text { I N T E R N A T | O N A L M O N E T A R Y F U N D }
$$




\title{
IMF Working Paper
}

Western Hemisphere Department

Proximity and Horizontal Policies:

\section{The Backbone of Export Diversification and Complexity}

Prepared by Gonzalo Salinas ${ }^{1}$

Authorized for distribution by Sònia Muñoz

March 2021

\begin{abstract}
IMF Working Papers describe research in progress by the author(s) and are published to elicit comments and to encourage debate. The views expressed in IMF Working Papers are those of the author(s) and do not necessarily represent the views of the IMF, its Executive Board, or IMF management.
\end{abstract}

\begin{abstract}
The lack of a clear link between general economic fundamentals and export diversification indicators in the literature has fueled the believe that industrial policies are an absolute requisite to diversify exports. This paper, however, does find a strong statistical connection between horizontal policies and diversification by making two novel changes to traditional methodologies: using export categories that lead to diversification (for example, manufactures) as dependent variables, and using a gravity-equation regression setting. Proximity to other economies explains about a third of cross-country heterogeneity in targeted exports, and four fifths together with horizontal policies. Australia, Chile, and New Zealand emerge as new role models for diversification policies.
\end{abstract}

\section{JEL Classification Numbers: F1, O1, O4}

Keywords: International trade, economic growth, economic development, export diversification, export complexity.

Author’s E-Mail Address: gsalinas@imf.org

\footnotetext{
${ }^{1}$ Thanks to Tang Li for UN Comtrade data download, Luiggi Silva for formatting, and to Reda Cherif, Rahul Giri, Metodij Hadzi-Vaskov, Adam Jakubik, Yothin Jinjarak, Martin Kaufman, Norman Loayza, Brad McDonald, Giovanni Melina, Montfort Mlachila, Sònia Muñoz, Chris Papageorgiou, Ferdinand Rauch, Sidra Rehman, Luca Ricci, Nikola Spatafora, Jacopo Timini, Anthony Venables, Andrew Warner, Alejandro Werner, Ermias Weldemicael, Yoto Yotov, and participants of seminars at the IMF and World Bank for their extremely valuable comments.
} 


\section{Contents}

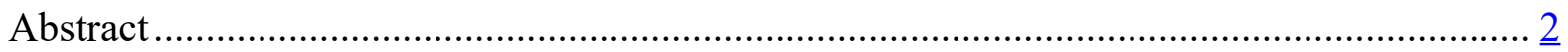

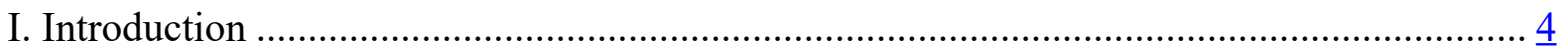

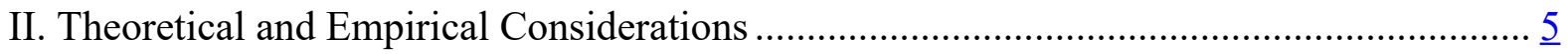

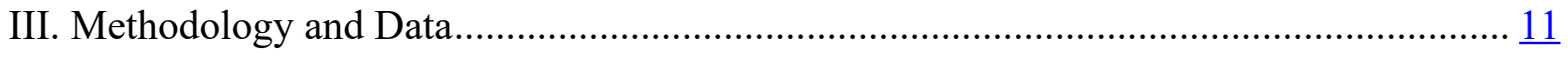

IV. Description of Key Variables ........................................................................ 14

V. Main results: What Explains Diversification and Superior Exports? ............................ 19

A. Identification of Determinants .............................................................................. 19

B. Analysis of Fit: Predictive Power of Proximity and Horizontal Policies.................... $\underline{23}$

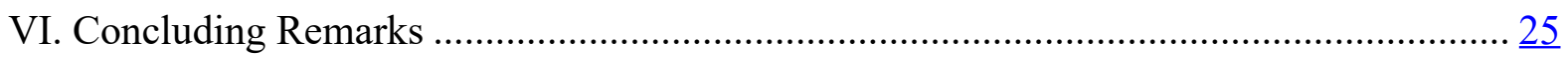

Annex Tables

Table A.1: Determinants of Economic Complexity Index (ECI) and ECI Plus ................... $\underline{32}$

Table A.2: List of Countries by Regional Group....................................................... $\underline{33}$

Table A.3: Determinants of exports by regression specification .................................... $\underline{37}$

Table A.4: Summary Results by Study ................................................................... 45

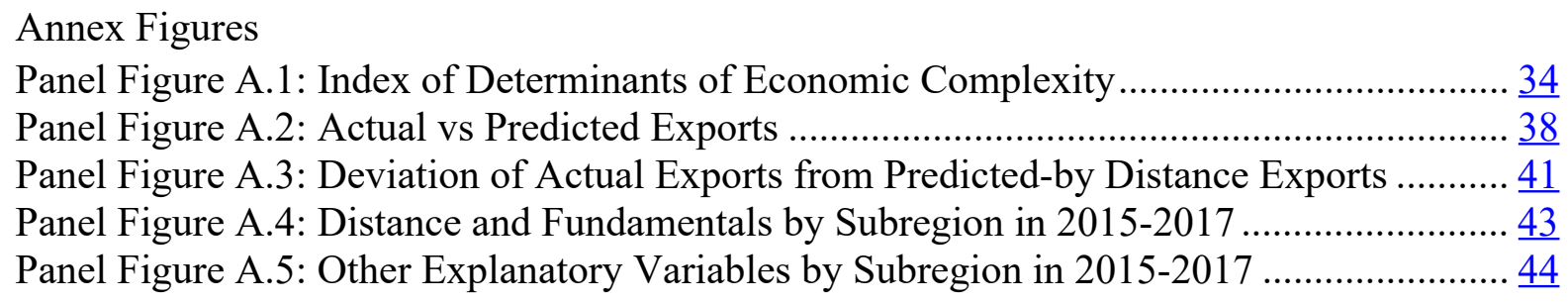




\section{INTRODUCTION}

Export diversification is a commonly sought objective in emerging and developing economies for several reasons. Numerous studies indicate that a more diversified export basket is statistically associated with lower output volatility (Haddad and others, 2013), and that the latter is associated with higher long-term output growth (Ramey and Ramey, 1995; Hnatkovska and Loayza, 2004). This is of outmost importance to most developing countries, as their export baskets tend to be concentrated on a handful of raw commodities with highly volatile international prices. Moreover, production of raw commodities is not labor intensive, and therefore it is argued that nurturing other more labor-intensive export sectors could improve labor market outcomes and socioeconomic conditions.

Some economists further suggest that there are some superior products that countries should export because they are expected to have higher economic payoff in different ways. Hallak (2006) classifies export products according to their quality and shows that advanced economies tend to import more of those higher quality products. Products are classified according to their sophistication in Hausmann and others (2006), and complexity in Hidalgo and Hausmann (2009), and these studies suggest that having more sophisticated/complex exports is associated with higher future economic growth.

While there are several studies aiming to identify policies that lead to export diversification and the development of superior exports, there are important caveats in their methodological approaches. First, the dependent variables commonly used are indices (such as concentration, sophistication, or complexity indices) that are greatly affected by exogenous changes in international commodity markets, which weakens their link to policy variables. Second, the explanatory variables included are commonly limited to those associated with higher productivity (for example, education, institutions), neglecting the importance of labor costs and gravity equation-related variables for exports development (especially of manufacturing products) according to standard trade models.

This paper therefore makes two fundamental shifts in the analysis of export diversification and its policy determinants. Instead of using diversification/concentration, sophistication, or complexity indices as dependent variables, it uses levels of export categories (nonhydrocarbon/mineral (NHM), manufacturing, services, complex) that can diversify commodity dependent export baskets. ${ }^{2}$ In addition, following a standard Eaton and Kortum (2002) Ricardian model, it adds gravity equation and labor costs variables to the commonly included productivity-related independent variables. Income per capita is introduced as a control for endogeneity and removed for goodness of fit estimation.

The proposed methodological changes allow for a substantial estimation improvement as coefficients are more robustly significant and goodness of fit is higher than in other studies.

\footnotetext{
${ }^{2}$ In this paper, the term NHM exports includes only goods not services. Service exports are identified separately for analytical purposes as their dependence on distance and economic policies is considerably different from that of NHM goods exports.
} 
The analysis finds a strong relation between gravity related variables and NHM, manufacturing, complex, and service exports. It also finds that governance, educational attainment, infrastructure quality, and trade policy openness are robustly related to these exports. Adding these horizontal policies to countries' proximity to international markets explains above 80 percent of cross-country variation in the targeted exports.

The paper first discusses in more detail, in Section II, the justification for the two analytical shifts proposed above, while Section III delineates this methodological approach. Section IV describes the regional and country level variation in NHM exports, as well as in independent variables. Econometric analysis in Section $\mathrm{V}$ statistically identifies the factors that are associated with the development of targeted exports and their explanatory power. Section VI discusses the main policy implications of these statistical findings.

\section{Theoretical AND EMPIRICAL CONSIDERATIONS}

\section{The Dependent Variable}

Most empirical attempts to identify the factors that foster export diversification use as dependent variable an export concentration index, such as the Herfindahl-Hirschman Index (HHI), while those aiming to identify the determinants of superior exports use several indices of exports superiority, such as the Exports Sophistication Index (ESI) (Hausmann and others, 2005; Weldemicael, 2012) or the Economic Complexity Index (ECI) (Hidalgo and Hausmann, 2009).

Nevertheless, these indices are substantially affected by exogenous factors, thus weakening their statistical link to policy determinants. Take for instance the HHI of export concentration for country $j$ including exports $(x)$ of several sectors $(s)$ :

(1) $H H I_{j}=\sum_{s}\left(\frac{x_{s j}}{\sum_{s} x_{s j}}\right)^{2}$

This index is higher when the nominal export value of one or few commodities is high relative to the total export basket, indicating more (less) exports concentration (diversification). In most developing countries, partly due to their weak production capacity, a handful of hydrocarbon/mineral (HM) exports account for most of their total exports. Hence when aiming to diversify exports these countries seek policies to nurture NHM products. If successful, the value of these products will narrow the gap with respect to the dominant HM exports and this would reduce their HHI.

But the HHI can also significantly fluctuate in response to variations in the nominal value of their HM exports, which are commonly the result of largely exogenous events such as changes in international commodity prices or findings of additional HM reserves. Such fluctuations can considerably weaken the statistical relationship between policy frameworks and the targeted development of NHM exports needed to diversify export baskets. 
This is quite evident when looking at the evolution of the concentration index in a commodity exporting country. For instance, Chile's HHI in the early 2000s markedly reverted its previously downward trend in the absence of any substantial reform to its policy framework (see figures below). This surge in concentration is most evidently related to the international copper boom, which multiplied the value of Chile's copper exports from US\$ 8 billion in 2003 to a peak of US\$ 54 billion in 2011, when it accounted for half of its goods exports. The continued growth in per capita NHM exports during that period confirms that the surge in export concentration was not related to a weakening in Chile's NHM export potential. Because most countries that seek export diversification are strongly dependent on HM exports, this disconnect between the HHI and policy determinants of NHM exports due to commodity fluctuations is highly consequential.
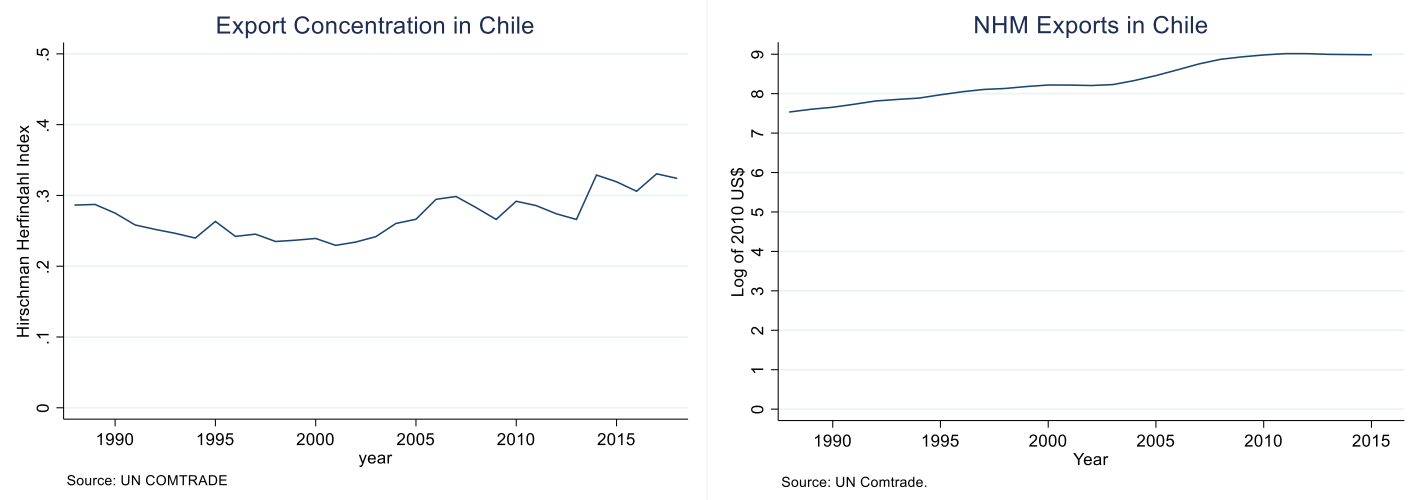

A similar complication occurs when trying to identify a statistical relation between policy variables and superior exports by using sophistication or complexity indices as dependent variables. These indices are broadly a product of the sophistication/complexity of each exported product times the product's share in the country's export basket. For instance, the ESI of country $j$ is calculated as the sum of the sophistication (PRODY) of each exported product weighted by its share in its total exports:

(2) $E S I_{j}=\sum_{s}\left(\frac{x_{j s}}{\sum x_{j s}}\right) P R O D Y_{s}$

In turn, product sophistication is calculated as the weighted average of GDP per capita of the countries exporting product $s$, where the weight is the value-share of product $s$ in country's $j$ overall export basket divided by the value-shares across all countries exporting that good:

(3) $P R O D Y_{s}=\sum_{j} \frac{\left(\frac{x_{j s}}{\sum_{i} x_{j s}}\right)}{\left(\sum_{j}\left(\frac{x_{j s}}{\sum_{i} x_{j s}}\right)\right)} G P D p c_{j}$

Hence, a product is estimated as more sophisticated when it is mainly produced in higher income countries. Because HM exports dominate the export baskets of lower GDP per capita countries, in general, HM exports are estimated as less sophisticated than NHM exports: 
(4) $P R O D Y_{H M}<P R O D Y_{N H M}$

Since exports $(x)$ are measured in nominal values, exogenous increases in international HM prices or HM discoveries lower the ESI without any change in sophisticated exports. Regression specifications that aim to establish a link between policies and sophisticated exports are thus weakened by exogenous commodity related fluctuations. A similar analysis applies for the $\mathrm{ECI}^{3}$.

Chile during the early 2000 s is also an illustrative case of how these indices can mislead the identification of policies that foster superior exports. Chile's ECI plummeted from close to zero in 2000 to -0.6 in 2015 , a considerable fall as the ECI broadly ranges between -2.5 and 2.5. This decline seems at odds with the sustained productivity growth that Chile experienced those years which, a priori, should have increased its capacity to produce complex goods for exporting. As was

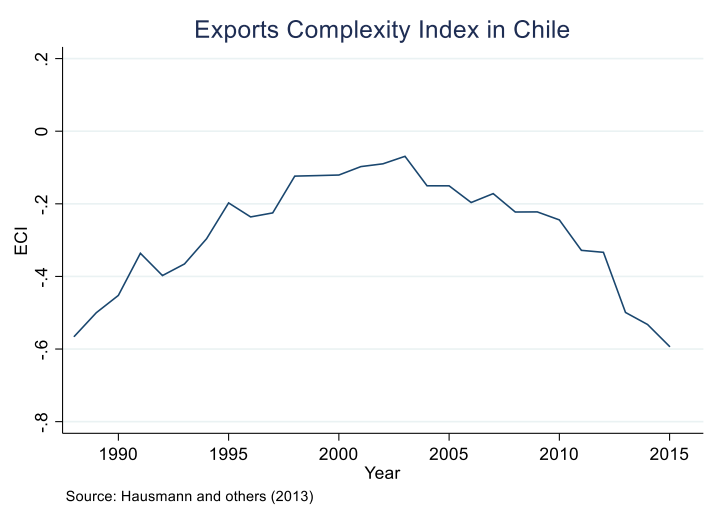
the case with the HHI, Chile's ECI decline is most evidently related to the boom of copper (a low complexity product), thus showing how commodity fluctuations erode the relation between target variable (complex exports) and policy variables. ${ }^{4}$

The disconnect between the ECI and a country's policy framework is similarly evident in cross-country comparisons. A priori, the advanced Australian economy, with strong institutional and educational quality, should be more capable of producing complex products than Latin American countries. Yet, for example, the ECI of Australia is considerably below the ECIs of El Salvador and Honduras. According to its authors the ECI is a proxy for productive capabilities and

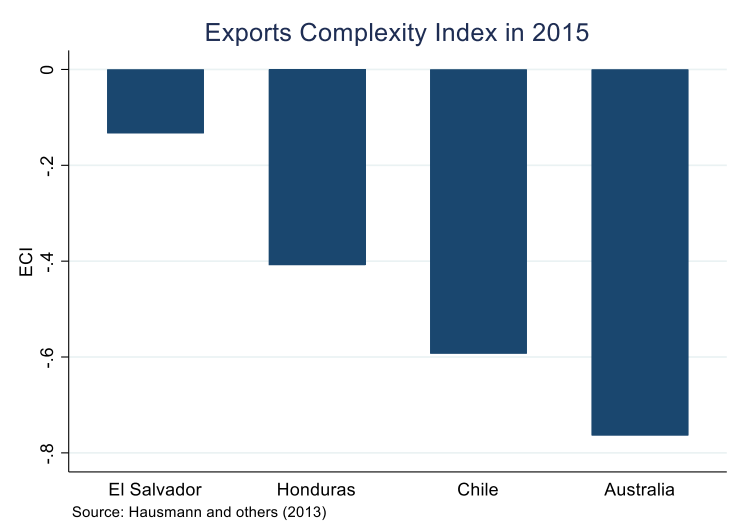

\footnotetext{
${ }^{3}$ The ECI of a country is calculated based on the diversity of exports a country produces and their ubiquity, or the number of countries able to produce them (and those countries' complexity). This index aims to measure the knowledge in a society in terms of the products it exports (Hausmann and others, 2013), but this is questionably the case as it is substantially affected by commodity fluctuations that are not related to the knowledge or productivity of economic agents.

${ }^{4}$ As an example of a similar disconnect in oil exporting countries, Nigeria's ECI has considerably deteriorated during oil price booms (in the early 1970s and early 2000s) and improved significantly in 2008, as a result of the oil price collapse of that year. At a regional level, as noted in Ding and Hadzi-Vaskov (2017), a growing trend in the share of complex exports in Latin American and Caribbean in the 1990s was reversed in the 2000s because of the commodity price boom, as the region is a major exporter of these products.
} 
measures the knowledge of a society (Hausmann and others, 2013), but it is questionable that Australia's productive capabilities are inferior in this illustrative cross-country comparison. Australia's low ECI is likely related to its exogenously high mineral endowment and consequent high exports of minerals, which are low complexity products.

Another illustrative case of the limitations of the ECI as a measure of complexity due to natural resource abundance is the U.S. state of Texas. Despite being a global technology leader its ECI is only 0.29 , similar to the Philippines. This evident inconsistency likely results from Texas superlative petroleum endowments and the extremely low (-2.57) Product Complexity Index (PCI) of Petroleum Oils in Hausmann and others (2013).

This dependency of the ECI on exogenous commodity developments is systemic across countries. Fixed effect regressions including most countries (Table A.1) indicate that the ECI is strongly associated with resource wealth as defined in Sachs and Warner (1995). It is thus likely that the ECI's statistical relation with future GDP growth described in Hidalgo and Hausmann (2009) is related to the resource curse identified earlier in several studies including in Sachs and Warner (1995).

The evident disconnect between the above discussed indices and policy determinants that foster diversification and export superiority can be effectively addressed by focusing directly on the evolution of the export products that lead to diversification or export superiority. Since export diversification is commonly sought in countries that are dependent on a handful of HM exports, the relevant dependent variable is the value of NHM, manufacturing, and/or services exports. And when aiming to foster superior exports the dependent variable can be directly defined as the value of those superior exports itself. These dependent variables can be normalized by population or labor force to control for size.

An alternative solution to deal with the weakened link between the HHI and diversification policy determinants would be to remove HM exports from the calculation of the HHI. In practice, however, there is hardly any country that has an export basket concentrated on few NHM products and therefore strongly needs to diversify its NHM export basket. A statistical analysis of HHI excluding NHM exports as dependent variable would thus have little practical relevance. A similar option, to calculate an ECI excluding HM exports to measure a country's complexity, would not accurately measure the overall knowledge of society in cases in which a small, non-representative elite is capable of exporting complex products but most of society does not export and is involved in low productivity activities. ${ }^{5}$

Fixed effects regressions in Table A.1 and the correlation table below show that complex exports per capita is positively associated with the ECI. Central to the analysis in this paper, this matrix also shows that the ratio of complex exports per capita is not significantly

\footnotetext{
${ }^{5}$ One can think of many developing countries in which a very small elite group produces complex exports, but the export basket is dominated by HM products and most of the labor force is involved in a low-productivity informal economy. Such country would have a high ECI excluding HM exports, but this would be a poor measure of the overall knowledge of society. On the other hand, the country's level of complex exports per capita would surely capture the weak productive capabilities of its overall economy.
} 
correlated to the ratio of HM exports to GDP. The ratio of complex exports per capita, as intended, is not affected by natural resource abundance and commodity price fluctuations, which should improve the identification of the factors that foster the development of complex exports.

\begin{tabular}{lcccc}
\multicolumn{6}{l}{ Correlation ECI, natural resource abundance, and complex exports per capita } \\
\hline & ECI & ECI Plus & $\begin{array}{c}\text { HM exports } \\
\text { to GDP }\end{array}$ & $\begin{array}{c}\text { Exports Per } \\
\text { Capita (Log) }\end{array}$ \\
& & & & \\
ECI & 1.00 & 1.00 & & \\
ECI Plus & 0.91 & -0.17 & 1.00 & 1.00 \\
HM exports to GDP & -0.23 & 0.76 & 0.07 & \\
Log Complex Exports Per Capita & 0.76 & & & \\
\hline Source: Hausmann and others (2013) and author's calculations.
\end{tabular}

The analysis substantially changes when focusing directly on the evolution of the targeted export groups per capita. As seen above, although Chile's HHI pointed to declining diversification in the early 2000s, NHM exports per capita continued to increase during that period. The picture similarly changes when looking directly at the value of per capita complex exports, which can be defined, for instance, as those in the upper half of the PCI (with PCI above zero). Unlike the ECI, the real value of Chile's complex exports per capita continued to grow during the copper boom and, as expected, complex exports per capita is higher in Australia than in Honduras and El Salvador.
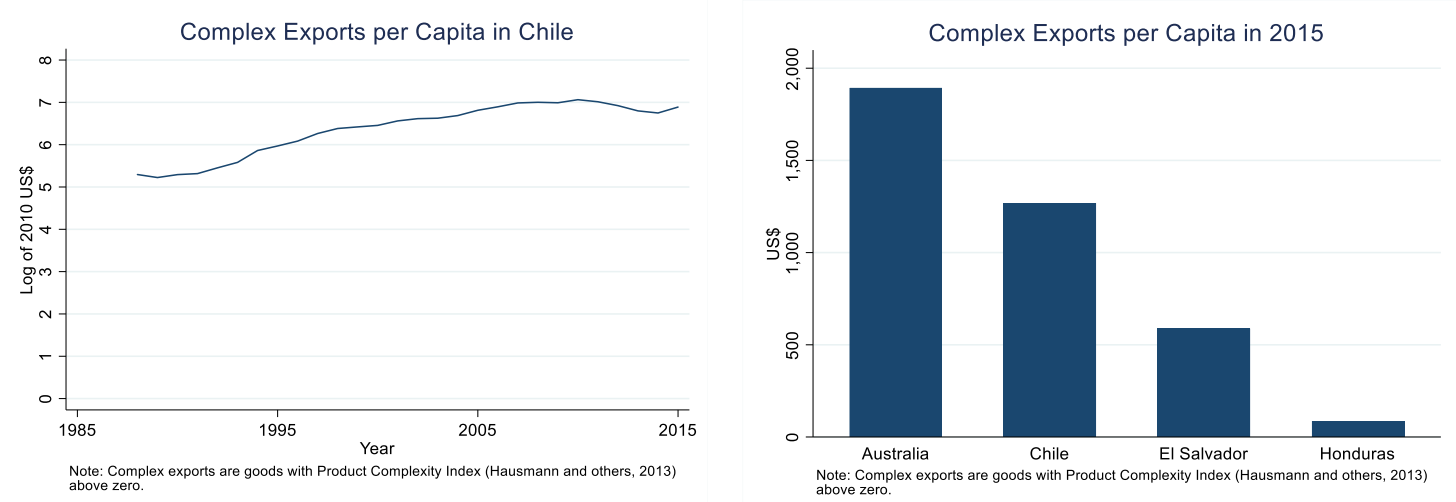

\section{Independent Variables}

Another fundamental shift needed to sharpen the identification of factors that foster export diversification and superior exports is basing regression specifications on standard trade theory. This second shift is partly related to the first one, as the dependent variables proposed are levels of exports (not indices) and these have been extensively modelled in the international trade literature. 
The analysis can thus be broadly rooted, for example, on a standard EK02 (Eaton and Kortum, 2002) Ricardian general equilibrium model, which takes into accounts distance and labor costs in addition to productivity. We can relate the target export categories (NHM, manufacturing, complex, and services) to the manufacture sector in EK02's two-sector setting of manufactures and non-manufactures: ${ }^{6}$

$$
\frac{X_{n i}}{X_{n}}=T_{i}\left(\frac{\gamma d_{n i} w_{i}^{\beta} p_{i}^{1-\beta}}{p_{n}}\right)^{-\theta}
$$

where the fraction of total expenditure of country $\mathrm{n}$ on manufacturing goods from country $i$ $\left(X_{n i}\right)$ divided by its total expenditure $\left(X_{n}\right)$, is a function of country $i$ 's state of technology $\left(T_{i}\right)$, wages in country $i\left(w_{i}\right)$, and prices in both countries. ${ }^{7}$ Note that while distance-related variables are mostly exogenous, those related to technology and wages are largely determined by public policies of the exporting economy.

Other empirical studies on the determinants of export diversification and superior exports include independent variables that are related to productivity/technology (T-variables) of the exporting country $(i)$, but do not include wage and gravity-related variables. This omission implicitly assumes that labor costs and gravity-equation variables do not have a different effect in the targeted export groups (NHM or superior exports) from the non-targeted exports (homogeneous elasticities across exports types). A significant exception is Weldemicael (2012), which finds that distance to markets is strongly related to the ESI, thus implying a significant difference in the impact of distance on more sophisticated exports from less sophisticated exports. In line with this finding, the statistical analysis below identifies heterogenous elasticity-to-distance across several export groups.

Empirical findings from the GVC literature also hint at the importance of distance to large markets and other gravity equation variables in the development of superior exports. Raei and others (2019) and Kowalski and others (2015) identify gravity variables as key determinants of Global Value Chain (GVC) participation. Since participation in GVCs is seen as a major force behind the growth of more complex, manufacturing products, it is very likely that gravity-related variables are significant determinants of export superiority.

\footnotetext{
${ }^{6}$ Note though that since the EKO2 and a large class of international trade models generate isomorphic gravity equations (Arkolakis and others, 2012), the results of our analysis should be broadly robust to model selection.

${ }^{7}$ Parameter $\gamma$ is a measure of the sensitivity of local prices to foreign cost structures and geographic barriers. $\theta$ represents product homogeneity across countries, which governs comparative advantage. A low $\theta$ implies high product variability and in that case comparative advantage exerts a bigger force for trade. $\beta$ is labor's share in production, while $(1-\beta)$ is intermediate inputs' share in production.
} 


\section{Methodology ANd DATA}

Part of the analysis in this paper focuses on the value of each export category normalized by population to allow cross-country comparisons among exporters. Admittedly, NHM exports per capita are not totally immune to commodity booms and natural resource abundance. Commodity booms could trigger Dutch Disease dynamics attracting factors of production towards HM export sectors and away from NHM exports. As seen in the case of Chile in the early 2000s and as in the stylized facts charts presented below, this effect does not appear to be substantial within a country and across time. However, exports of HM products, for sure, use up significant labor, directly and indirectly, thereby reducing NHM exports per capita relative to non-commodity exporters. It is worth keeping this in mind especially in crosscountry comparisons of NHM exports per capita.

Normalizing by population also makes the dependent variable less sensitive to commodity fluctuations than alternative normalizations. Normalizing NHM exports by dividing them by GDP is ruled out as GDP in HM abundant countries by definition includes HM exports. Dividing NHM exports by GDP excluding HM sectors is similarly rejected because commodity boosts and busts indirectly affect other sectors, such as commerce and services.

A potential drawback of normalizing targeted exports through dividing by population is that such ratio can be exogenously affected by the share of the population in working age, which can affect cross-country and cross-time comparisons. This could hence weaken the link between policies and targeted exports and suggest normalization by the labor force could be preferable. Nonetheless, participation in the labor force can be endogenous to economic activity and therefore to policy determinants under consideration in this study. For example, if policy determinants are effective in fostering the targeted exports partly by increasing labor force participation, the exports-to-labor force ratio would be relatively unchanged and not reflect the success of those policies. In any case, the identification of policy determinants of diversification does not require normalization of the dependent variable and while the analysis on goodness of fit does require normalization, it is largely robust to normalization by labor force instead of population.

A preliminary panel econometric specification can be derived from equation (1), rearranging its terms, adding the time dimension, and log linearizing it: ${ }^{8}$

(6) $\quad X_{n i, t}=\alpha_{1} \log (\gamma)+\alpha_{2} \log \left(X_{n, t}\right)+\alpha_{3} \log \left(d_{n i}\right)+\alpha_{4} \log T_{i, t}+\alpha_{5} \log \left(w_{i, t}\right)+\vartheta_{\mathrm{ni}}+$ $\mu_{\mathrm{t}}+\varepsilon_{\mathrm{ni}, \mathrm{t}}$

where year $\left(\mu_{t}\right)$ and country-pair fixed effects $\left(\vartheta_{n i}\right)$ are introduced. In addition to distance between countries itself, other commonly used gravity equation variables (dummies for common currency, Free Trade Agreement, common border, common language, common

\footnotetext{
${ }^{8}$ Price variables are excluded for statistical estimation simplicity but will be indirectly considered when discussing below the introduction multilateral resistance terms.
} 
colonizer, and past colonial dummy) are included as they are also somehow related to the distance $\left(d_{n i}\right)$ concept in EK02.

Regression specifications in most related studies include T-variables such as institutional development, educational attainment, trade policy openness, and infrastructure development. ${ }^{9}$ These four variables appear significantly (though not robustly) associated with diversification, sophistication, and complexity in several studies (for example Hausmann and others, 2006; Weldemicael, 2012; Ding and Hadzi-Vaskov, 2017), including through Bayesian identification (Giri and others, 2019).

The analysis in this paper also identifies these four variables as the most economically and statistically significant in fostering diversification and complexity relative to other $\mathrm{T}$ variables. As highlighted in the gravity equation literature, exports are not only determined by policy variables of the exporting country, but also by policies of the importing country and therefore they are also included in regressions below. A labor market flexibility variable is introduced to partly capture the wage variable in EK02, assuming rigid labor markets inflate wage costs.

GDP per capita is added as an independent variable acknowledging that it can also approximate wage costs, but mainly to control for potential endogeneity between NHM exports per capita and T-variables. Higher NHM exports can foster GDP and higher GDP can help strengthening T-variables (for example, higher output can facilitate/finance higher educational attainment). Note though that GDP per capita is not included in the calculation of goodness of fit when estimating the predictive power of policy variables.

For estimation purposes EKO2, as well as many other international trade models, can be transformed into a gravity equation specification (Arkolakis and others, 2012). ${ }^{10}$ Therefore, some components are added to equation (6) to align it with a gravity equation specification, including: (i) GDP of the source country $(X i, t)$; (ii) a remoteness index variable of the importer as a reduced-form control for inward multilateral resistance $(R n, t)$; (iii) a remoteness index variable of the exporter as a reduced-form control for outward multilateral resistance $(R i, t)$; and (iv) T-variables of the importing country $\left(T_{n, t}\right):{ }^{11}$

\footnotetext{
${ }^{9}$ Trade policy openness and transport infrastructure can be alternatively considered proxies for effective distance between countries.

${ }^{10}$ Yotov and others (2012) provide a comprehensive discussion of gravity equation estimation challenges and techniques.

${ }^{11}$ Although including log GDP per capita and log GDP of the source country can add multicollinearity to the specification (the correlation among them in the sample is 0.5 ) this does not directly impact the main conclusions of this paper because: (i) the estimated coefficient of log GDP, which is used to calculate the equation (9), appears stable and statistically significant across regressions; (ii) conclusions based on equation (9) do not change if the coefficient is replaced by 1 (as commonly assumed in the gravity equation literature); main conclusions of the paper are not directly based on the coefficient of log GDP per capita.
} 


$$
\begin{aligned}
& +\alpha_{6} \log \left(\left(\frac{X}{N}\right)_{i, t}\right)+\alpha_{7} \log \left(X_{i, t}\right)+\alpha_{8} \log \left(R I_{n, t}\right)+\alpha_{9} \log \left(R I_{i, t}\right)+\alpha_{10} \log \left(T_{n, t}\right)+\vartheta_{\mathrm{ni}}+ \\
& \mu_{\mathrm{t}}+\varepsilon_{\mathrm{ni}, \mathrm{t}}
\end{aligned}
$$

As in Wei (1996) and Anderson and van Wincoop (2003), the remote index of a country $i$ is calculated as a weighted average of the distance of country $i$ to its trading partners $(n)$, where the weights are the incomes of trading partners $(X n):{ }^{12}$

$$
R I_{i}=\sum X_{n} \mathrm{~d}_{\mathrm{ni}}
$$

Since country-pair fixed effects terms are fully correlated with time invariant variables, equation (7) is estimated using the Hausman and Taylor (1981) instrumental variable technique. ${ }^{13}$

After estimating the elasticities of gravity and policy variables within the bilateral trade framework of equation (7), it proofs quite insightful to estimate their predictive power at the export country level. The model-predicted level of targeted exports of each country can hence be compared to their actual level to provide a sense of goodness of fit. A complication in doing this is aggregating gravity-equation related variables from the bilateral to the export country level in an intuitive manner. A simple route is to build a Proximity to Markets $(P M)$ index for each country, using $X_{n}$ and $d_{n i}$ of equation 7 and their coefficients:

(9) $\widehat{P M}_{i}=\sum \frac{x_{n}{ }^{\hat{\alpha}_{2}}}{d_{n i}{ }^{\hat{\alpha}_{3}}}$

As defined here the $P M$ index of country $i$ aggregates the economic size of all trading partners weighted by the inverse of their distance to country $i$. Intuitively, $P M$ is a measure of the trade-generating gravity pull that each country experiences. It is clearly an inverse concept of $R I$ defined in equation (8).

Predicted exports per capita of each country $(\mathrm{Xi} / \mathrm{Ni})$ are first calculated based only on the $P M$ 's "gravity pull":

\footnotetext{
12 The use of remoteness indices to control for multilateral resistance could be considered a second-best option, as Yotov and others (2012) suggests that a first-best option would be the use of exporter-time and importer-time fixed effects. However, this potentially first-best option would wash out the identification of the hypothesized determinants of the dependent variables in this study due to multicollinearity with the proposed fixed effects.

${ }^{13}$ Because the dependent variable in equation (3) is specified in logarithmic terms, zero trade flows cannot be included and therefore the information they could provide is neglected. While regressions on goods exports have strong statistical fit despite this omission, regressions on the smaller and less comprehensive set of service exports observations may be more affected by this omission. Yotov and others (2012) indeed suggests that the omission of zero trade flows is more significant for sectoral service trade due to their highly localized consumption and highly specialized production.
} 
(10) $\log \left(\frac{x_{i, t}}{N_{i, t}}\right)=\beta_{0}+\log \left(\widehat{P M}_{i, t}\right)$

and then based on $P M, T$ and $w$ variables, using their coefficients estimated in equation (7), which controlled for potential endogeneity through the inclusion of GDP per capita:

(11) $\log \left(\frac{x_{i, t}}{N_{i, t}}\right)=\beta_{1}+\log \left(\widehat{P M}_{i, t}\right)+\left(\hat{\alpha}_{4} \log T_{i, t}+\hat{\alpha}_{5} \log \left(w_{i, t}\right)\right)$

As indicated earlier the dependent variables of interest in this paper are those types of exports that are conducive to diversification and/or are identified as superior in some studies. These are, specifically, exports of NHM, manufacturing, complex, and service products. Based on SITC Revision 2 classification, the NHM group excludes codes 3000-4999, 6772-6999, and 9000-9999, while manufactures includes codes 6900-8999. Services excludes government services (code 11 under classification EBOPS 2002). Complex products include goods that in Hausmann and others (2013) have a PCI above zero (approximately the top half of the PCI ranking). ${ }^{14} \mathrm{~A}$ group including only HM exports is also analyzed for comparison purposes. The data source for exports of goods and services is UN's Comtrade (United Nations, 2020), which includes the Extended Balance of Payments Services (EBOPS) database.

Gravity equation variables are extracted from the CEPII gravity database constructed by Head and others (2010) and Rose (2004). ${ }^{15}$ Variables measuring political stability and governance are extracted from Polity IV (2014) and World Bank (2020a), respectively. Educational attainment data was retrieved from the United Nations Education index (UNDP, 2020) and Barro-Lee (Barro and Lee, 2013). Tariff data comes from the World Integrated Trade Solution (World Bank, 2020b). Infrastructure quality and other measures of Tvariables come from the Global Competitiveness Report (World Economic Forum and Harvard University, 2020) and the Doing Business database (World Bank, 2020c). Labor market flexibility is approximated through related subindices in the Global Competitiveness Report and in International Monetary Fund (2019).

\section{DESCRIPTION OF KEY VARIABLES}

Interesting patterns stand out when looking at per capita levels of the export categories associated with diversification and superior exports. In a regional comparison, the level of NHM exports per capita appears associated with GDP per capita (see figure below). Even though some Eastern European (EE) and East Asian Emerging Market (EAEM) countries are commonly considered champions of diversification because of their low concentration indices, the higher income, natural resource abundant countries in Scandinavia (SCN) and Oceania (OCE, Australia and New Zealand) have considerably higher levels of NHM exports

\footnotetext{
${ }^{14}$ The Product Complexity Index is available at $<\underline{\text { https://atlas.cid.harvard.edu/rankings/product }}>$.

${ }^{15}$ Available at http://www.cepii.fr/cepii/en/bdd_modele/bdd.asp.
} 
per capita ${ }^{16}$. And notwithstanding their higher export concentration indices, Southern Cone (SCC) countries (Argentina, Brazil, Chile, Paraguay, and Uruguay) have in average a similar level of NHM exports per capita as EAEM and Central American countries (CAM). This confirms the discussion above suggesting that concentration indices are not an accurate reflection of the development of NHM exports.

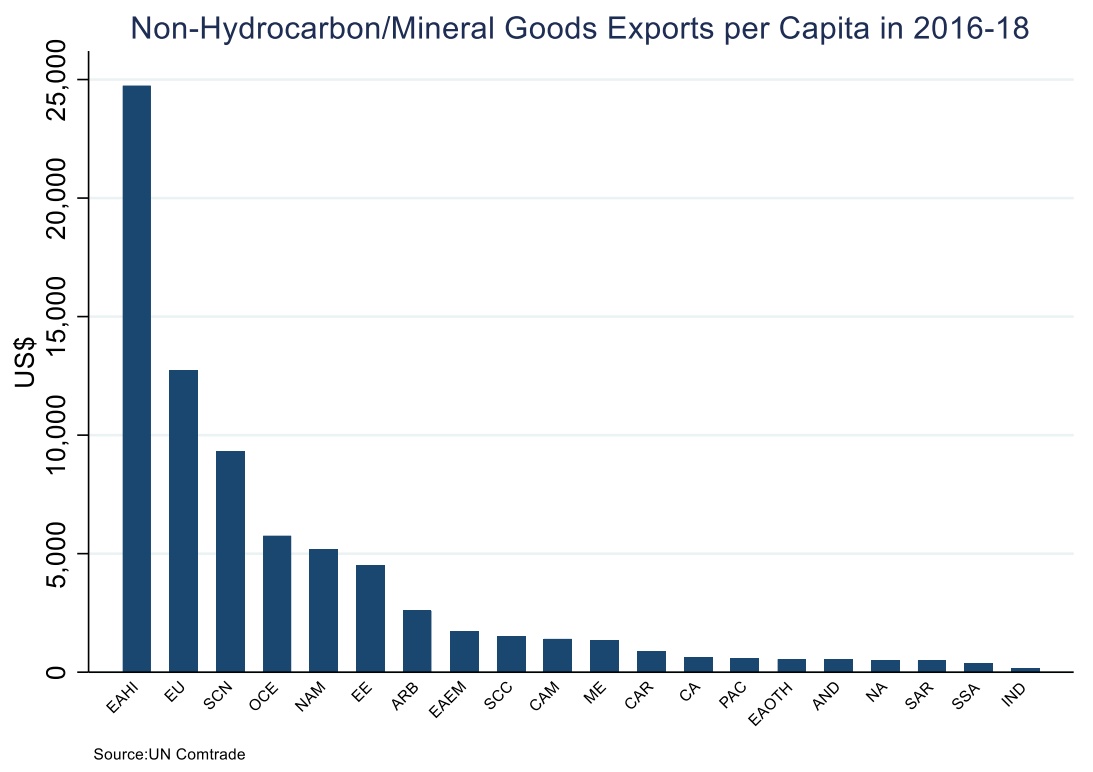

But while there is a close relation between income and NHM exports the association is far from perfect. For instance, although natural resource abundant SCN and OCE countries have a higher income per capita than EU countries, their NHM exports per capita are significantly lower. Also prominent is the superlative level of NHM exports per capita of East Asian HighIncome economies (EAHI, Hong Kong, Japan, Singapore, South Korea, and Taiwan), even though their income per capita is not considerably different from that of EU and SCN countries.

At least two characteristics seem to explain these misalignments between income per capita and NHM exports per capita. One is that, as discussed earlier, even if the production of HM exports is not particularly labor-intensive, the share of labor it demands directly is not negligible, and the share of labor employed in industries and services that support HM production is significant. With less labor force available to other sectors, NHM exports per capita is expected to be lower in countries with significant HM exports. This then could partly explain why HM intensive OCE and SCN countries have lower NHM exports per capita than other countries with similar income per capita.

A second characteristic that can explain the misalignments is that EAHI and other countries that are close to large international markets and therefore participate more intensively in GVCs, have gross NHM exports that overstate their domestic value added. According to the

\footnotetext{
${ }^{16}$ Regional acronyms are described in Table A.2.
} 
OECD Trade in Value Added (TIVA) database (OECD, 2019), the domestic value added of NHM exports in remote Australia and Chile is 81 and 88 percent of their gross exports, respectively, while the value added in EAHI and EAEM economies is around 60 percent. ${ }^{17}$

The dynamics of NHM exports per capita is also revealing (see panel figure below). In contrast to indices of export diversification and of superior exports, NHM exports do not appear affected by commodity prices as they grew resiliently in HM-exporting Andean (AND), SCC, and Sub-Saharan African (SSA) regions throughout the 2000s commodity boom.

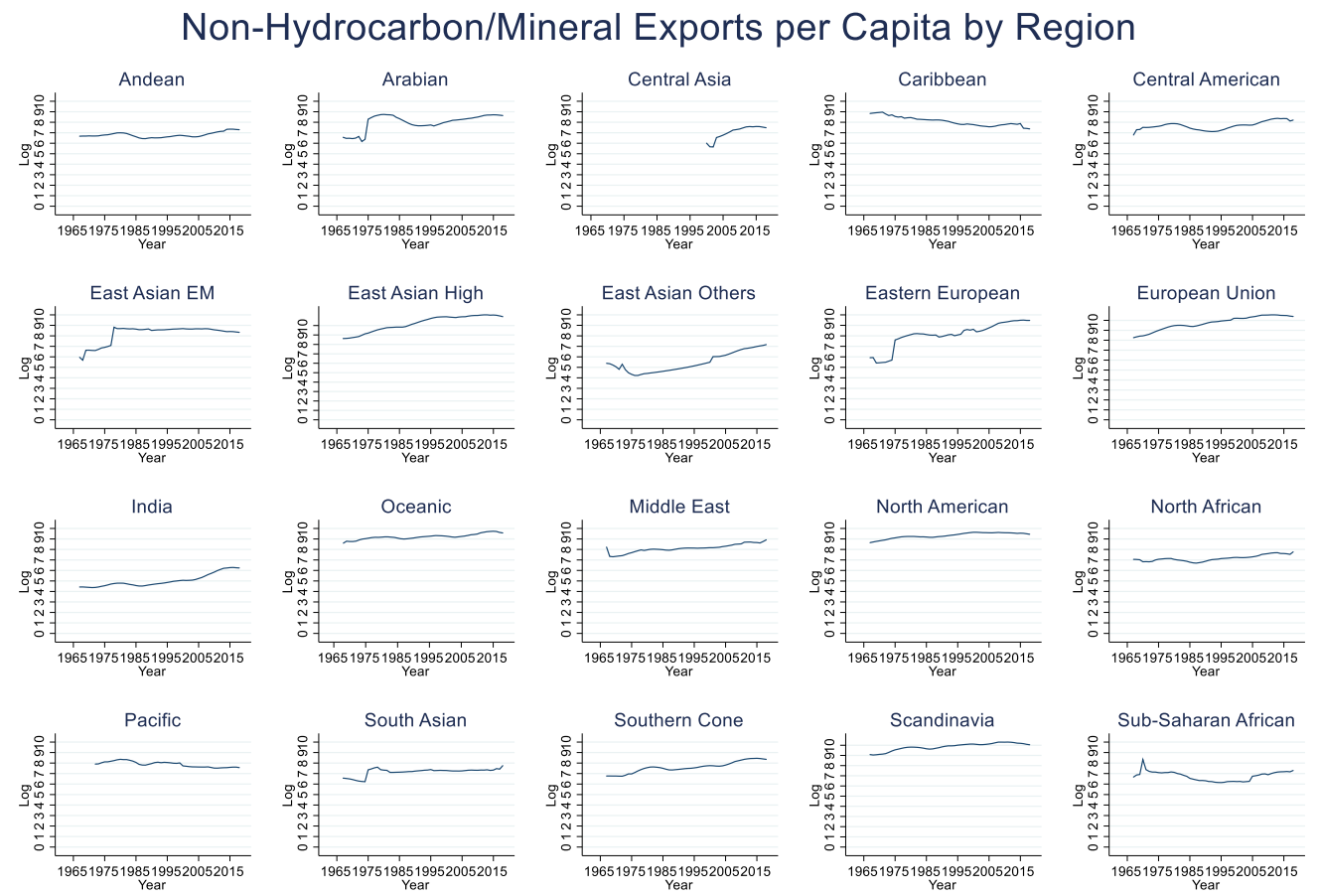

Source: UN Comtrade

Another important pattern observed in these charts is that NHM exports growth has been faster in regions such as CAM, EE, EAEM, and EAHI, that are closer to the largest world economic centers. East Asian countries exhibited high growth since the 1960s, but their growth decelerated in recent decades. This slowdown does not seem related to a convergence dynamic because EAEM countries decelerated before reaching the level of EAHI countries. NHM exports growth in CAM and EE countries, conversely, accelerated in recent decades, broadly following their economic/trade liberalization episodes. Some remote regions, such as OCE and SCC have also experienced faster NHM exports growth following liberalization episodes.

\footnotetext{
${ }^{17}$ Data on exports value added is not available for most countries, therefore the rest of the analysis centers on gross exports. Note that all indices of diversification and export "superiority" are subject to this caveat.
} 
A country-level view of NHM exports growth broadly confirms these regional patterns and provides further insights (see panel figure below). Countries close to large international markets such as Costa Rica, El Salvador, Poland, Malaysia, and Indonesia show the fastest NHM growth, and countries that undertook strong trade liberalization like Costa Rica, Chile, El Salvador, Poland, experienced an acceleration in the aftermath of these reforms. Also remarkable is the stagnation in NHM exports in countries previously considered models of diversification, such as Dominican Republic and Mauritius. These countries though have dynamic services sectors (mainly tourism) that are not included in these charts showing NHM goods exports.

Non-Hydrocarbon/Mineral Exports per Capita by Country
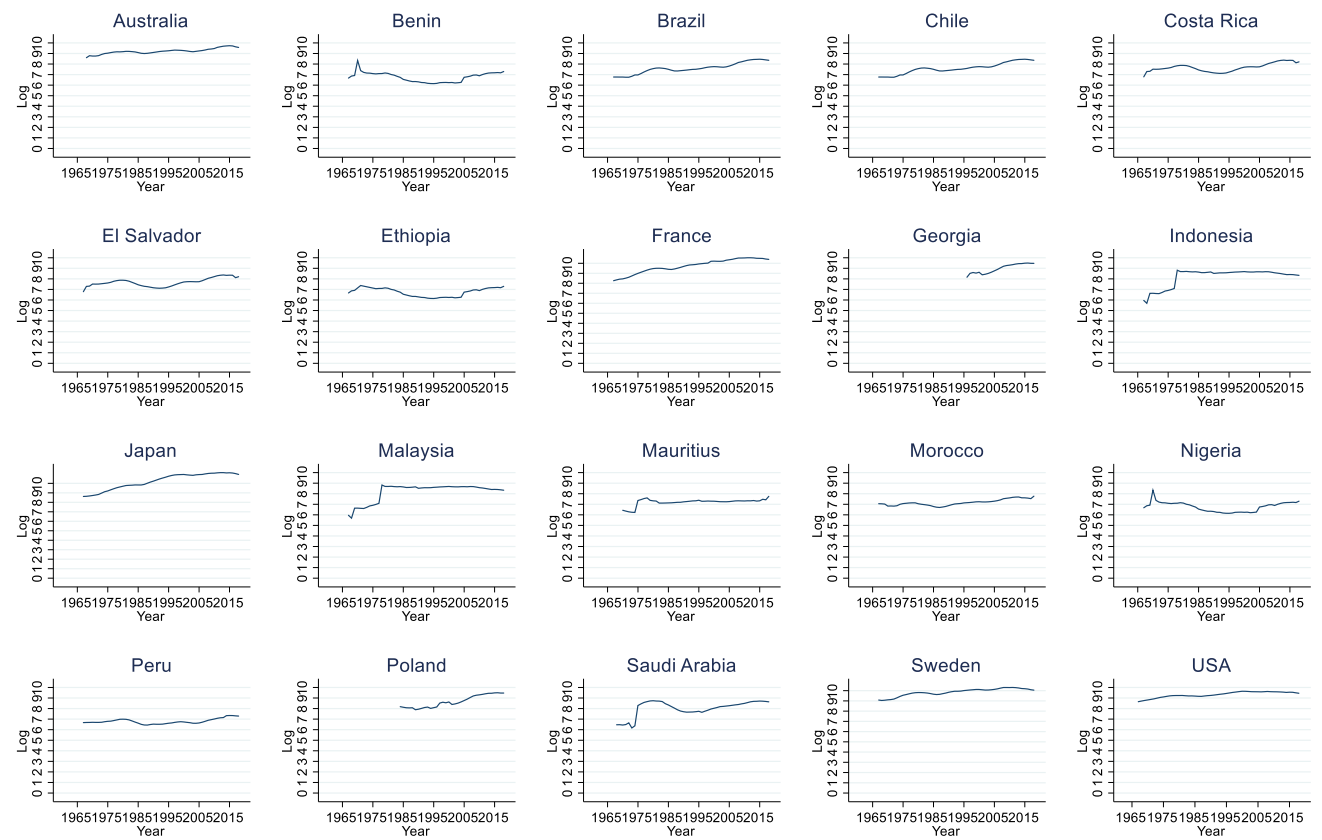

Source: UN Comtrade

Cross-regional comparisons of the $P M$ index confirms that distance to global economic centers appears closely linked to NHM export development The charts below confirm that regions with fast growth in NHM exports (CAM, EE, EAHI, and EAEM) have substantially higher $P M$ than most other emerging and developing regions. ${ }^{18}$ Remarkably, CAM and EE had very high $P M$ already in the 1960 s, but as noted earlier, they did not experience a sustained acceleration in NHM exports until they liberalized their trade regimes.

${ }^{18}$ Exponents $\hat{\alpha}_{2}$ and $\hat{\alpha}_{3}$ in equation (9) are equal to one in these charts. 


\section{Proximity to markets}
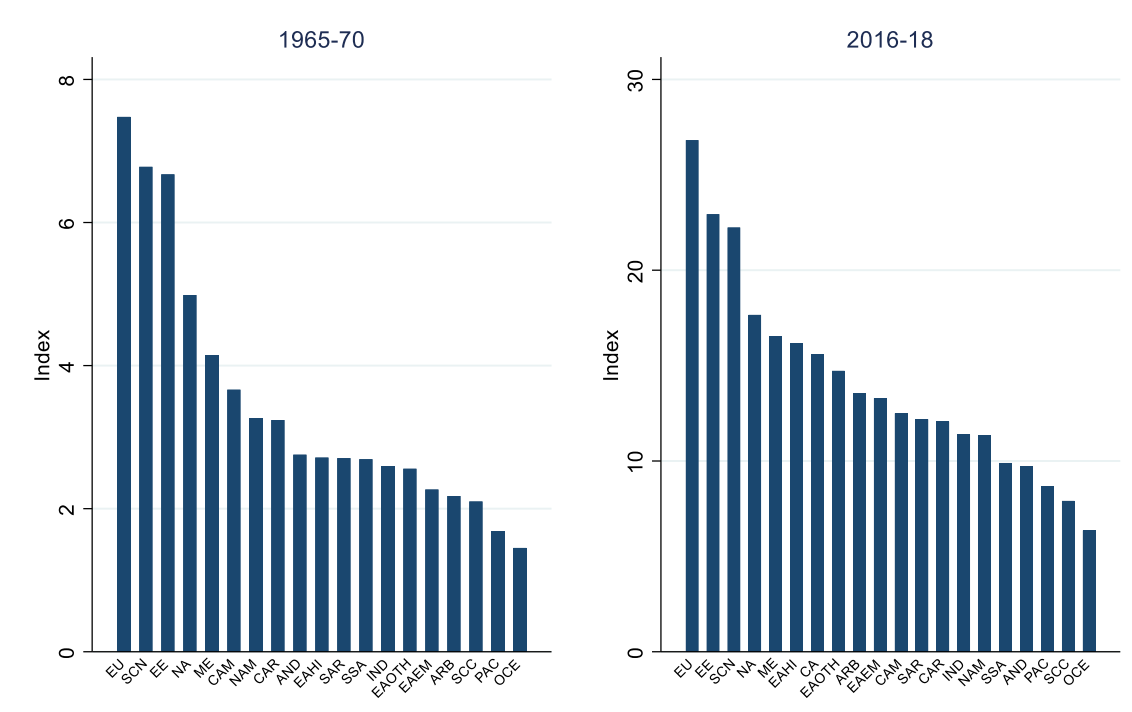

Source: CEPIl gravity database constructed by He
Note: Proximity to Markets defined in equation (9).

Already in the 1960s, East Asian countries benefitted from a significantly higher $P M$ than many emerging economies. In fact, $P M$ of South Korea in 1965 was about 70 percent higher than SCC, a factor that could significantly help explain the often-noted higher export performance of South Korea. The high PMs of South Korea and other East Asian countries in the 1960s reflected their proximity to the large and already industrialized Japanese economy, which was not only beneficial as a source of nearby demand but also of capital and technology transfer.

The largeness of the East Asian economic agglomeration and its efficient sea-based interconnection are clearly an advantage relative to the relative isolation of countries in Oceania, Sub-Saharan Africa, and South America. ${ }^{19}$ Furthermore, the higher PM of East Asian countries has substantially increased in recent decades, as their high $P M$ s have fostered their economies and the growth of their economies have further increased their PMs (a virtuous circle).

Panel Figure A.1 shows the evolution of T- variables since the 1960s. Many decades ago, EAHI countries already had superior education and infrastructure as well as lower trade barriers than other developing countries, and they improved their relative standing in decades after. This could also help explain their sustained high export performance. Eastern European countries had superlative education in the 1960s, but they improved their relatively weak infrastructure and open their relatively closed trade policies only since the 1980s.

\footnotetext{
19 The higher $P M$ in East Asia than South America and Sub-Saharan countries is likely higher if estimated based on travel time among countries, not distance among them. East Asian countries are easily and closely connected through the sea, whereas South American and Sub-Saharan African countries are mainly separated by difficult land geographies.
} 


\section{MAIN RESUlts: What EXPLAINS DiVERSIFICATION AND SUPERIOR EXPORTS?}

\section{A. Identification of Determinants}

Regressions based on equation (7) confirm the importance of proximity/distance to large global markets for export diversification and the development of superior exports. The coefficient of distance to partner country in a first regression including only gravity-equation variables (see table below, column 1), indicates that reducing distance by half is associated with a 150 percent increase in NHM exports. Note that the $P M$ of the remote SCC and OCE regions is about half of that of CAM, EE, and East Asian regions and therefore the exogenous distance factor on its own can explain a substantially lower level of NHM exports per capita in these remote regions. The point estimate of the coefficient of distance does not change much when including other policy determinants in columns $2-4$. The coefficients of most other gravity equation variables are statistically significant and have the expected signs.

Determinants of non-hydrocarbon/mineral (NHM) exports

\begin{tabular}{|c|c|c|c|c|}
\hline Dependent Variable: Log NHM exports & (1) & (2) & (3) & (4) \\
\hline Log GDP reporter & $1.527 * * *$ & $0.660 * * *$ & 0.16 & $0.825 * * *$ \\
\hline Log GDP partner & $0.386^{* * *}$ & 0.22 & \multicolumn{2}{|c|}{$0.030 .159^{*}$} \\
\hline Log distance & $-1.471 * * *$ & $-1.247 * * *$ & $-1.240^{* * *}$ & $-1.329 * * *$ \\
\hline Common currency dummy & $0.386^{* * *}$ & 0.22 & 0.03 & $0.159^{*}$ \\
\hline Free trade agreement dummy & $0.232 * * *$ & $0.177 * * *$ & $0.131 *$ & $0.188^{* * *}$ \\
\hline Common border dummy & $0.328 * *$ & $1.971^{* * *}$ & $1.837 * * *$ & $1.383 * * *$ \\
\hline Common language dummy & $0.753 * * *$ & $0.619 * * *$ & $0.316^{* *}$ & $0.573 * * *$ \\
\hline Common colonizer dummy & $0.836^{* * *}$ & $0.253^{*}$ & $0.716^{* * *}$ & $0.473 * * *$ \\
\hline Past colonial link dummy & $1.534 * * *$ & $1.338 * * *$ & $1.501^{* * *}$ & $1.481 * * *$ \\
\hline Log GDP per capita & $-0.341 * * *$ & -0.08 & $0.644 * * *$ & $0.272 * * *$ \\
\hline Governance (WB Index) & & $0.457 * * *$ & $0.176^{* *}$ & \\
\hline Education (UN Index) & & $4.854 * * *$ & $3.550 * * *$ & \\
\hline Infrastructure (GCR Index) & & $0.169 * * *$ & $0.283 * * *$ & \\
\hline Average Tariff & \multicolumn{4}{|c|}{$-0.0299 * * *-0.0429 * * *$} \\
\hline Labor market flexibility (GCR Index) & \multicolumn{4}{|c|}{0.021} \\
\hline Labor market flexibility (IMF Index) & \multicolumn{4}{|c|}{$2.861 * * *$} \\
\hline Political stability (Polity IV) & \multicolumn{4}{|r|}{$-0.0177 * * *$} \\
\hline Education (Barro Lee) & \multicolumn{4}{|r|}{$0.0438 * * *$} \\
\hline Infrastructure (WDI) & \multicolumn{4}{|r|}{$0.0238 * * *$} \\
\hline Trade liberalization (Wacziarg and Welch, 2003) & \multicolumn{4}{|r|}{$0.517 * * *$} \\
\hline Constant & $-21.94 * * *$ & 0.48 & $15.44 * * *$ & $-4.178 *$ \\
\hline Observations & 169,968 & 44,989 & 31,253 & 90,352 \\
\hline Rho & 0.76 & 0.94 & 0.96 & 0.86 \\
\hline $\begin{array}{l}\text { Notes: }{ }^{*} \mathrm{p}<0.1,{ }^{* *} \mathrm{p}<0.05,{ }^{* * *} \mathrm{p}<0.01 \text {. Panel reg } \\
\text { with groups consisting of all combinations of repo } \\
\text { Observations are non-overlapping } 5 \text {-year averages } \\
\text { availability. Regression specification based on eq } \\
\text { country's policy variables included (coefficients } \mathrm{n} \\
\text { value of exports excluding hydrocarbon and miner } \\
8999 \text { ). Trade liberalization dummy based on ident } \\
\text { Welch (2008), with a value of } 1 \text { if the country has }\end{array}$ & $\begin{array}{l}\text { nn based on } \mathrm{H} \\
\text { nd partner cou } \\
\text { in the 1962-20 } \\
\text { (7). Multilate } \\
\text { orted). Depen } \\
\text { ducts (SITC2 } \\
\text { ion of trade lib } \\
\text { alized. }\end{array}$ & $\begin{array}{l}\text { Jausman and } \\
\text { untries in UN } \\
18 \text { period, de } \\
\text { eral resistance } \\
\text { dent variable } \\
\text { codes } 0-299 \\
\text { beralization e }\end{array}$ & $\begin{array}{l}\text { Taylor (1981 } \\
\text { Comtrade da } \\
\text { epending on } d \\
\text { e terms and p } \\
\text { is the logarit } \\
9,4000-6772 \\
\text { pisodes in W }\end{array}$ & $\begin{array}{l}\text { 1) technique } \\
\text { atabase. } \\
\text { data } \\
\text { partner } \\
\text { ithm of the } \\
2,6900- \\
\text { Vacziarg and }\end{array}$ \\
\hline
\end{tabular}

The statistical and economic significance of T- variables in the second column regression is also remarkable, particularly of education. A one standard deviation increase in educational attainment is associated with a 170 percent increase in NHM exports, while same increases in governance and infrastructure quality increase them by also significant 65 and 20 percent, respectively. Consistent with the noticeable acceleration in NHM exports after trade liberalization episodes shown above, reducing the average import tariff from 15 to 5 percent is associated with a significant 45 percent increase in NHM exports. Labor market flexibility is not significant when measured by the Global Competitiveness Report subindex, but a one 
standard deviation increase in the IMF labor subindex appears associated with a 45 percent increase in NHM exports in the third column regression. ${ }^{20}$

The fourth regression substantially extends the sample back in time by using the Polity IV political stability index as a proxy for governance; an index of railroad, phone lines, and electricity coverage as a proxy for infrastructure; and, as a proxy for trade policy, a binary variable with value of one if the trade policy regime has been liberalized according to Wacziarg and Welch (2008). In addition, the Barro-Lee education attainment indicator replaces the UN indicator and is interpolated in missing years. The estimated coefficients confirm the importance of these variables except for political stability. The coefficient of the liberalization dummy implies that liberalization episodes in Wacziarg and Welch (2008) are associated with an 80 percent increase in NHM exports per capita.

The significance of these policy determinants remains robust to the inclusion of other Tvariables in the Doing Business and Global Competitiveness reports (see table below). Doing Business variables are statistically significant, but estimated coefficients imply only singledigit percent impact of a standard deviation change on NHM exports. As expected, a one standard deviation increase in the overall Doing Business score appears more effective, as it is associated with a 15 percent increase of NHM exports. Among variables in the Global Competitiveness Index, technological readiness has a high magnitude and statistical significance, implying that a standard deviation increase in this variable is associated with a 10 percent increase in NHM exports.

Other determinants of non-hydrocarbon/mineral (NHM) exports

\begin{tabular}{|c|c|c|c|c|}
\hline Dependent Variable: Log non-hydrocarbon/mineral exports & (1) & (2) & (3) & (4) \\
\hline Log distance & $-1.247 * * *$ & $-1.265 * * *$ & $-1.237 * * *$ & $-1.223 * * *$ \\
\hline Governance (WB Index) & $0.457 * * *$ & $0.391 * * *$ & $0.339 * * *$ & $0.353^{* * *}$ \\
\hline Education (UN Index) & $4.854 * * *$ & $4.526 * * *$ & $4.402 * * *$ & $4.528 * * *$ \\
\hline Infrastructure (GCR Index) & $0.169 * * *$ & $0.157 * * *$ & $0.0809 * *$ & $0.136^{* * *}$ \\
\hline Average tariff & $-0.0299 * * *$ & $-0.0255 * * *$ & $-0.0241 * * *$ & $-0.0246^{* * *}$ \\
\hline Labor market flexibility (GCR Index) & 0.02 & 0.0363 & 0.0084 & 0.0390 \\
\hline Construction permits (Doing Business) & & 0.00 & 0.00 & \\
\hline Getting credit (Doing Business) & & $0.00177^{* *}$ & $0.00158^{*}$ & \\
\hline Investment protection (Doing Business) & & $0.00288^{* *}$ & $0.00317^{* *}$ & \\
\hline Paying taxes (Doing Business) & & 0.00 & 0.00 & \\
\hline Contract enforcement (Doing Business) & & 0.00 & 0.00 & \\
\hline Resolving insolvency (Doing Business) & & $0.00178^{*}$ & $0.00194 * *$ & \\
\hline Macroeconomic environment (GCR Index) & & & $-0.0332 *$ & \\
\hline Technological readiness (GCR Index) & & & $0.0976^{* * *}$ & \\
\hline Business sophistication (GCR Index) & & & 0.11 & \\
\hline Innovation (GCR Index) & & & 0.08 & \\
\hline Doing Business Score & & & & $0.0155^{* * *}$ \\
\hline Constant & 0.48 & -2.86 & -2.20 & $-9.129 * *$ \\
\hline Observations & 44989 & 44704 & 44704 & 44110 \\
\hline Rho & 0.94 & 0.95 & 0.95 & 0.95 \\
\hline \multicolumn{5}{|c|}{$\begin{array}{l}\text { Notes: }{ }^{*} \mathrm{p}<0.1,{ }^{* *} \mathrm{p}<0.05,{ }^{* * *} \mathrm{p}<0.01 \text {. Panel regressions based on Hausman and Taylor (1981) technique with } \\
\text { groups consisting of all combinations of reporter and partner countries in UN COMTRADE database. } \\
\text { Observations are non-overlapping 5-year averages within the } 1965-2017 \text { period, depending on data availability. } \\
\text { Regression specification based on equation (3). Gravity equation variables, multilateral resistance terms and } \\
\text { partner country's policy variables included but coefficients not reported. }\end{array}$} \\
\hline
\end{tabular}

${ }^{20}$ Table A. 3 shows that coefficients of policy variables the regression in column 2 remain economically and statistically significant to several regression specifications. 
higher HM exports, likely because these exports are more dependent on resource endowment than on the policy environment.

Other determinants of non-hydrocarbon/mineral (NHM) exports

\begin{tabular}{|c|c|c|c|c|}
\hline Dependent Variable: Log non-hydrocarbon/mineral exports & (1) & (2) & (3) & (4) \\
\hline Log distance & $-1.247 * * *$ & $-1.265 * * *$ & $-1.237 * * *$ & $-1.223 * * *$ \\
\hline Governance (WB Index) & $0.457 * * *$ & $0.391 * * *$ & $0.339 * * *$ & $0.353^{* * *}$ \\
\hline Education (UN Index) & $4.854 * * *$ & $4.526 * * *$ & $4.402 * * *$ & $4.528 * * *$ \\
\hline Infrastructure (GCR Index) & $0.169 * * *$ & $0.157 * * *$ & $0.0809 * *$ & $0.136^{* * *}$ \\
\hline Average tariff & $-0.0299 * * *$ & $-0.0255^{* * *}$ & $-0.0241 * * *$ & $-0.0246^{* * *}$ \\
\hline Labor market flexibility (GCR Index) & 0.02 & 0.0363 & 0.0084 & 0.0390 \\
\hline Construction permits (Doing Business) & & 0.00 & 0.00 & \\
\hline Getting credit (Doing Business) & & $0.00177^{* *}$ & $0.00158 *$ & \\
\hline Investment protection (Doing Business) & & $0.00288^{* *}$ & $0.00317 * *$ & \\
\hline Paying taxes (Doing Business) & & 0.00 & 0.00 & \\
\hline Contract enforcement (Doing Business) & & 0.00 & 0.00 & \\
\hline Resolving insolvency (Doing Business) & & $0.00178^{*}$ & $0.00194 * *$ & \\
\hline Macroeconomic environment (GCR Index) & & & $-0.0332 *$ & \\
\hline Technological readiness (GCR Index) & & & $0.0976^{* * *}$ & \\
\hline Business sophistication (GCR Index) & & & 0.11 & \\
\hline Innovation (GCR Index) & & & 0.08 & \\
\hline Doing Business Score & & & & $0.0155 * * *$ \\
\hline Constant & 0.48 & -2.86 & -2.20 & $-9.129 * *$ \\
\hline Observations & 44989 & 44704 & 44704 & 44110 \\
\hline Rho & 0.94 & 0.95 & 0.95 & 0.95 \\
\hline \multicolumn{5}{|c|}{$\begin{array}{l}\text { Notes: } * \mathrm{p}<0.1, * * \mathrm{p}<0.05, * * * \mathrm{p}<0.01 \text {. Panel regressions based on Hausman and Taylor (1981) technique with } \\
\text { groups consisting of all combinations of reporter and partner countries in UN Comtrade database. Observations } \\
\text { are non-overlapping } 5 \text {-year averages within the } 1962-2017 \text { period, depending on data availability. Regression } \\
\text { specification based on equation (7). Dependent variable is the logarithm of the value of exports excluding } \\
\text { hydrocarbon and mineral products (SITC2 codes } 0-2999,4000-6772,6900-8999 \text { ). Gravity equation variables, }\end{array}$} \\
\hline
\end{tabular}

As hinted by stylized facts, regression analysis also shows that the gravity pull from being close to larger international markets and an open trade regime appear positively related to NHM exports growth not just to their level. In a simple dynamic regression with growth of NHM exports per capita as dependent variable and $P M$, GDP per capita, and the Wacziarg and Welch (2008) trade liberalization dummy as independent variables, the coefficients of $P M$ and trade liberalization are positive

\begin{tabular}{lrr}
\multicolumn{3}{c}{ Annual growth of exports on potential determinants. } \\
\hline Dependent Variable: & $\begin{array}{c}\text { NHM exports } \\
\text { per capita }\end{array}$ & $\begin{array}{c}\text { HM exports } \\
\text { per capita }\end{array}$ \\
\hline Lagged growth of dependent variable & 0.649 & 0.012 \\
& 0.00 & 0.233 \\
$\log$ (Proximity to Markets) & 0.143 & 0.353 \\
& 0.000 & 0.328 \\
Log(GDP per capita) & -0.013 & -0.166 \\
& 0.001 & 0.210 \\
Trade Liberalization dummy & 0.059 & 0.386 \\
& 0.000 & 0.090 \\
& & 5372 \\
Observations & 5575 & 5 \\
Notes: Results from System GMM regressions. P-values below coefficients. Trade \\
liberalization dummy basd on Wacziarg and Welch (2008). Data from UN \\
Comtrade.
\end{tabular}
and statistically significant. The point estimate of the $P M$ coefficient implies that doubling $P M$ is associated with a 15 percentage points higher annual growth in NHM exports, while the point estimate of the trade liberalization coefficient implies that these episodes are followed by a 6 percentage points acceleration in NHM exports growth. ${ }^{23}$ A similar regression on HM exports per capita growth finds this variable strongly related to trade liberalization, but not as much with $P M$.

${ }^{23}$ The $P M$ coefficient implies that the difference in $P M$ between Malaysia and Chile (Malaysia's $P M$ is 60 percent higher than Chile's) more than explains Malaysia's 2.8 percentage points higher average growth in its NHM exports per capita since the 1960s. 


\section{B. Analysis of Fit: Predictive Power of Proximity and Horizontal Policies}

Being located close to large economic centers is a critical advantage for the development of exports conducive to export diversification. This is most evident in a scatter plot (see figure below) comparing actual levels of NHM exports per capita versus those predicted only by $P M$. The correlation between both variables is 0.54 and the R-squared of a fitted line indicates that a quarter of the variation in NHM exports is predicted by countries' exogenous proximity to other economies. ${ }^{24}$

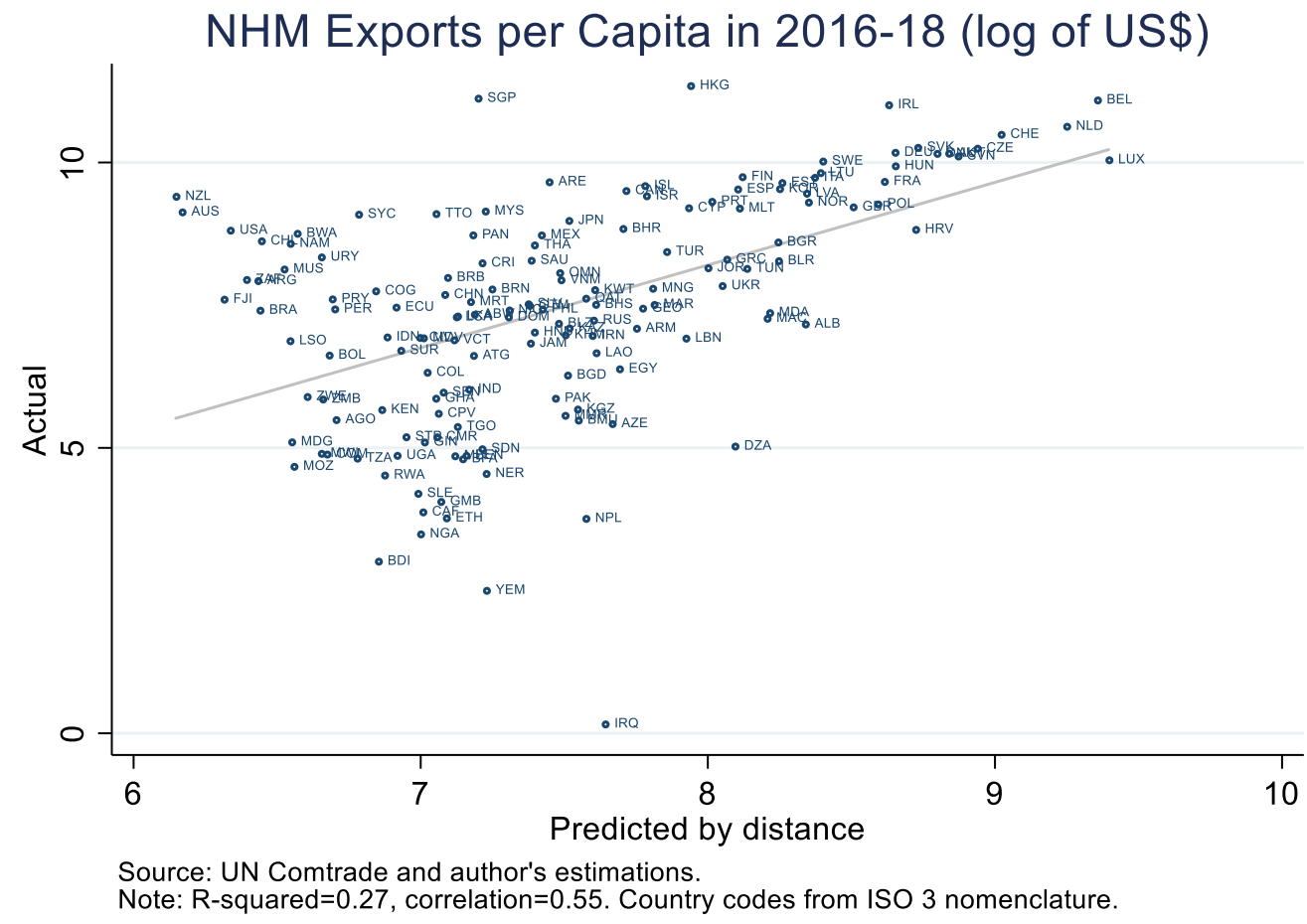

As previous regressions results suggest, the predictive power of $P M$ is similarly important for other subcategories of goods exports, except for HM exports, as seen in Panel Figure A.2. Countries that significantly deviate upward from the fitted line in the NHM exports scatter plot similarly deviate in scatter plots of complex and manufacturing exports. ${ }^{25}$ Both correlation and R-squared statistics are lower for HM and service exports. Large deviations in the scatter plot of HM exports are related to natural resource abundance, as expected. ${ }^{26}$

\footnotetext{
24 The fitted line has a slope equal to one (a 45-degree line).

25 The fitted lines of these carts also have slopes equal to one (45-degree lines).

${ }^{26}$ The last two charts in Panel Figure A.2 show that the model's goodness of fit does not change significantly when normalizing NHM exports by workforce instead of population.
} 
Countries that are above their fitted lines very likely have strong diversification-conducive policies that allow them to surpass geographically determined expectations and can therefore hint at "role models" of diversification policies. These include many remote countries, such as Australia (AUS), Chile (CHL), and New Zealand (NZL). The upward deviation of AUS and NZL is remarkably high, higher than that of many well-known role models of diversification, such as Korea (KOR), Japan (JAP), or Malaysia (MYS). Panel Figure A.3 shows deviations from $P M$-predicted NHM and complex exports per capita on a world map.

The predictive power of combining $P M$ and policy explanatory variables is impressive, with R-squared and correlation coefficient increasing up to 0.82 and 0.90 , respectively. ${ }^{27}$ In fact, no country with the $P M$ and policy variables of most Sub-Saharan African or Latin American countries has the level of NHM exports per capita of Japan, Korea, or Malaysia. It seems therefore that countries cannot simply bypass the need to strengthen their horizontal institutional, educational, infrastructure, trade, and labor policy framework. This is similarly the case for the development of complex, manufacturing, and service exports as inferred from scatter plots in Panel Figure A.2. ${ }^{28}$

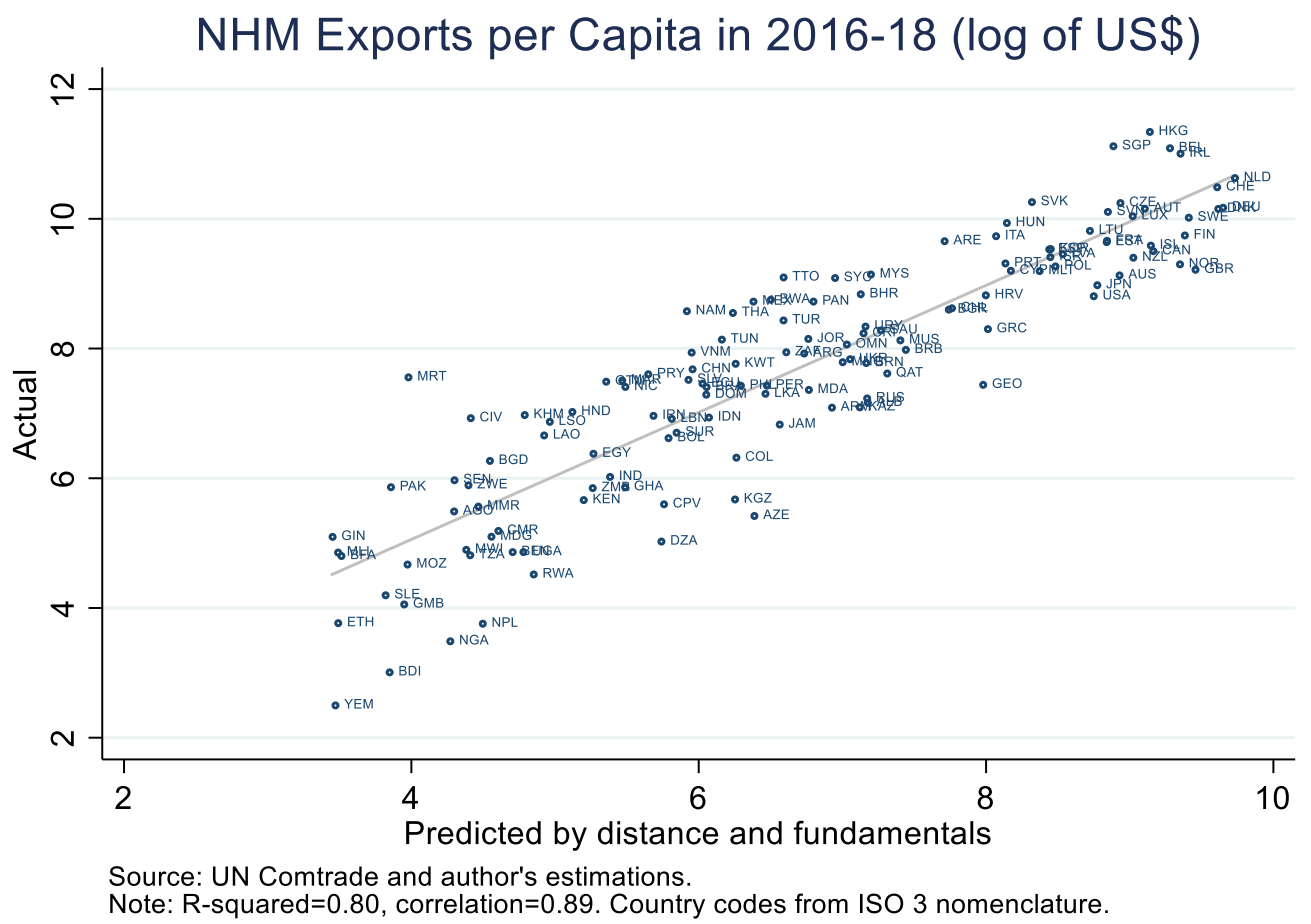

The remarkable improvements in fit for some countries (for example, Chile, OCE, EAHI) when adding predictive policy variables suggest that their success is largely associated with their strong horizontal policies. Their policy strength is clearly appreciated in cross regional comparisons in Panel Figures A.4 and A.5.

\footnotetext{
${ }^{27}$ All scatter plots use policy explanatory variables and coefficients from the second regression in page 19 .

${ }^{28}$ The slopes of the fitted lines of the charts on NHM, manufacturing, and complex exports are equal to one (45degree lines).
} 
Remaining outliers after incorporating horizontal policies to the prediction may be the result of vertical diversification policies but some can also reflect less-interesting idiosyncrasies. Positive outliers include countries that participate in GVCs (CAM, East Asia, EE) with high imported components, as noted earlier. Some small outliers are major trading pointsincluding Hong Kong, Panama, and Singapore - with exports that include reexports with low domestic value added. And many outliers are oil exporting countries with highly subsidized industries, which may be economically inefficient and therefore not clearly desirable models of diversification.

Aggregating actual and predicted NHM exports per capita at the regional level further clarifies the big picture. A scatter plot by regions broadly maintains the same R-squared and correlation coefficients as the plot by country. High performing EE countries have NHM exports per capita in line with prediction by $P M$ and policy variables identified in this paper. East Asian countries generally export above prediction, but also Central America (CAM) and Southern Cone (SCC) subregions. Sub-Saharan African countries' weak performance is broadly well predicted by its $P M$ and policies.

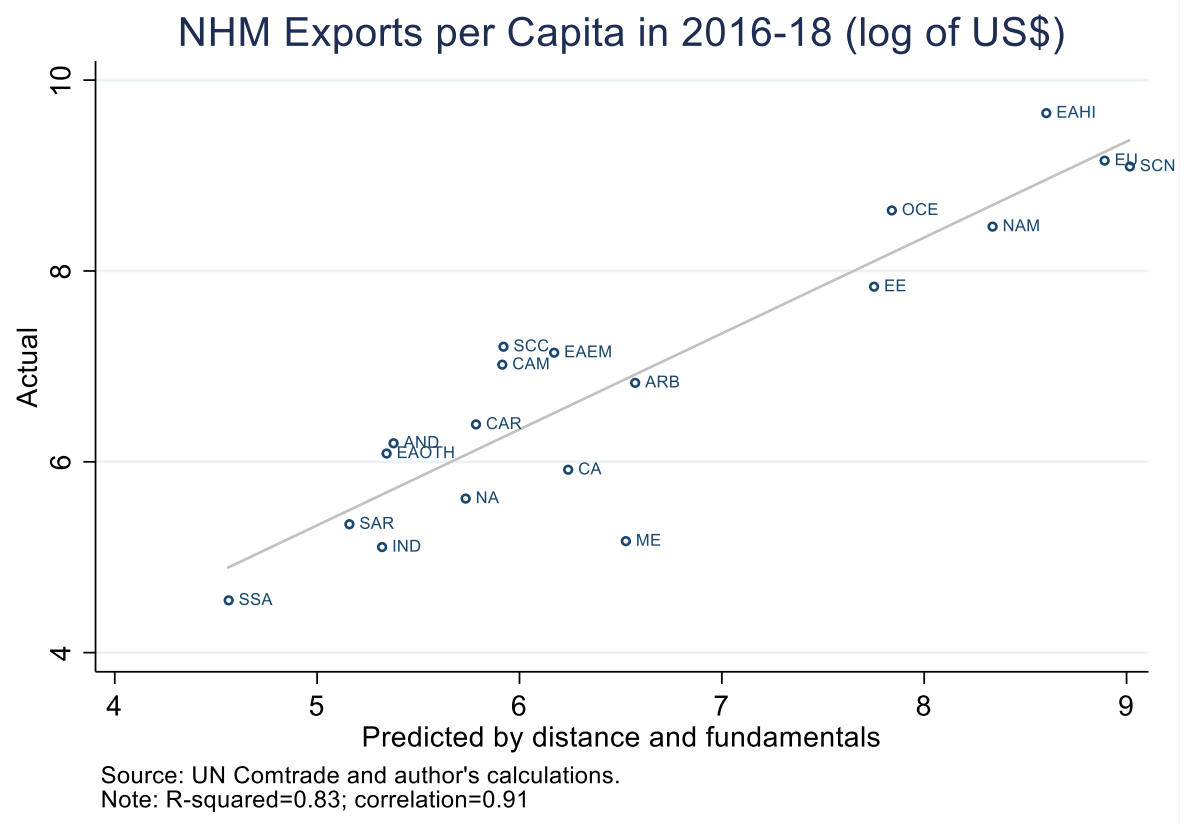

VI. CONCluding Remarks

This paper shows that to identify the determinants of export diversification it is better to analyze directly export groups associated with diversification instead of focusing on commonly used diversification indices because the latter are extremely sensitive to exogenous HM exports. For the same reason it is more accurate to identify determinants of superior exports by focusing on their level instead of commonly used indices. While the 
Economic Complexity Index (ECI) aims to be a proxy of the productive capabilities of an economic system, its sensitivity to commodity-related factors, completely unrelated to an economy's productivity, severely distorts its accuracy.

The data generating process of export categories linked to diversification can be modeled with high goodness of fit as a gravity equation with horizontal policy variables. $P M$ on its own explains about a quarter of the variation in NHM exports per capita and cutting distance to markets by half increases NHM exports by about 150 percent. The lower sensitivity of service exports suggests that they could provide a more feasible route to diversification for remote countries than goods exports. Interestingly, $P M$ is also associated with considerably higher growth rates of NHM and complex exports per capita. Table A.5 describes how identifying determinants of export diversification with the methodology proposed in this paper leads to more statistically robust estimates than other related studies.

The centrality of $P M$ underscores the need to effectively shorten distance to other economies by enhancing connectedness at all levels, reducing trade policy barriers, enhancing trade facilitation, strengthening transport infrastructure, investing in top-notch communication technology (particularly on internet connectivity to support the digital economy), and fostering technological diffusion (including through educational exchange programs). Enhancing connectedness is crucial for the most remote economies, thus better allowing their production agents to more significantly tap from backward and forward linkages to large global economic centers.

Adding policy variables related to the standard EK02 model, most of which have been identified less robustly in other studies, provides remarkably accurate predictions of crosscountry variation in NHM, complex, and manufacturing exports per capita. Such strong fits indicate that no country has the level of NHM exports per capita of East Asian high-performing economies if they have the $P M$ and quality of horizontal policy variables normally seen in Latin America or Sub-Saharan Africa. The importance of the identified policy variables is most clearly appreciated in countries that have high NHM exports per capita despite their remoteness (notably Australia, Chile, and New Zealand), as they seem to have been able to significantly offset the natural drawback of distance via strong policy frameworks.

Strengthening horizontal policy areas such as institutions, education, technological readiness, may seem a daunting and extremely long-term task, but significant payoff can be obtained from short-to-medium term reforms that reduce trade policy barriers, strengthen infrastructure, and remove excessively restrictive regulations, including of the labor market. Note also that within the wide objective of governance strengthening, more focused reforms to improve government effectiveness and control corruption seem particularly productive. And concentrating on strengthening port and electricity infrastructure seems most important among all infrastructure areas.

The identified statistical importance of horizontal policies does not necessarily deny some potential contribution from sector-specific policies. One potential reason is that the effective application of vertical policies could be partly correlated with horizontal policy covariates. It 
is quite possible that vertical policies are more successfully implemented in countries with higher government effectiveness, better control of corruption, and overall education.

In fact, the identified horizontal policy determinants of diversification could shed light to some second-best sector-specific interventions to offset economy wide policy/institutional weaknesses, such as is sometimes done through Special Economic Zones (SEZs). One such case happened in Mauritius in the 1970s. With high imports restrictions (average tariffs at around 100 percent) and rigid labor market legislation, this country fostered export diversification and complexity by setting up SEZs without import restrictions and with a flexible labor legislation, including one of the lowest minimum wage-to-GDP ratios in the world. These schemes most likely played an important role in Mauritius' notable export development, together with its relatively high overall institutional strength and educational quality.

Countries could similarly strengthen diversification determinants identified in this paper at a sector level without resorting to SEZs. For example, governments could provide technical education to strengthen a specific sector's productivity, develop sector-specific infrastructure, or impose lower restrictions on imported inputs to favored sectors, although this last option is more prone to rent seeking.

Given a long and vast history of sector-specific and industrial policy failures, any assessment of these policies should consider not only their potential effectiveness in promoting targeted exports but also the risk that they could lead to fiscal erosion, facilitate rent seeking, contribute to a "race to the bottom" in international taxation, or weaken multilateralism. In this sense, tax incentives, subsidized credit, exchange rate manipulation, sector-specific trade protection, are among the "riskier" options and there seems to be no strong evidence identifying the effectiveness of this kind of "hard industrial policies" (Harrison and Rodriguez-Claire, 2012). ${ }^{29}$ On the other hand, diversification strategies centered on strengthening horizontal policies are not only less controversial but, as the statistical analysis shown in this study suggests, constitute the backbone of export diversification.

\footnotetext{
${ }^{29}$ Harrison and Rodriguez-Claire (2012) reviews empirical work on industrial policy effectiveness and finds no support for "hard" interventions that distort prices. Several surveys have sought to provide evidence on the importance of industrial policies in promoting export diversification, particularly in East Asian countries (see for example, Rodrik, 2004; Rodrik, 2008; or Cherif and Hasanov, 2019). Yet, as Harrison and Rodriguez-Claire (2012) reflects, while it is clear that East Asian countries pursued industrial policies it is not clear that those policies should be credited for their successful industrialization, especially considering that these countries also exceled on horizontal policies, as shown in this WP. In addition, other studies have negatively assessed the role of industrial policies, notably since Caves and Uekesa (1976), which suggested that Japan's MITI created recession cartels and entry barriers that resulted in allocative inefficiency.
} 


\section{References}

Albeaik, Saleh, Mary Kaltenberg, Mansour Alsaleh, Cesar Hidalgo, 2017, "Improving the Economic Complexity Index," Papers 1707.05826, arXiv.org, revised Jul 2017.

Allen, Treb, Costas Arkolakis, Yuta Takahashi, 2020, "Universal Gravity," Journal of Political Economy, University of Chicago Press, vol. 128(2), pages 393-433.

Anderson James and Eric van Wincoop, 2003, "Gravity with Gravitas: A Solution to the Border Puzzle," American Economic Review, American Economic Association, vol. 93(1), pages 170-192.

Arkolakis, Costa, Arnaud Costinot and Andrés Rodríguez-Clare, 2012, "New Trade Models, Same Old Gains?" American Economic Review, American Economic Association, vol. 102(1), pages 94-130.

Bakker, Bas, Manuk Ghazanchyan, Alex Ho, and Vibha Nanda, 2020, "The Lack of Convergence of Latin America compared with CESEE and East and South-east Asia: Is Low Investment to Blame?” IMF Working Papers 20/98, International Monetary Fund.

Barro, Robert J. and Jong Wha Lee, 2013, "A new data set of educational attainment in the world, 1950-2010," Journal of Development Economics, Elsevier, vol. 104(C), pages 184198, retrieved from: $<$ http://www.barrolee.com/>.

Cadestin, Charles, Julien Gourdon and Przemyslaw Kowalski, 2016, "Participation in Global Value Chains in Latin America: Implications for Trade and Trade-Related Policy," OECD Trade Policy Papers 192, OECD Publishing.

Caves, Richard E. and Uekusa Masu, 1976, Industrial Organization in Japan,: The Brookings Institution, 1976. Pp. xi, 169, Washington, D.C.

Cherif, Reda and Hasanov Fuad, 2014, "Soaring of the Gulf Falcons: Diversification in the GCC Oil Exporters in Seven Propositions," IMF Working Paper WP/14/177, Washington DC.

Cherif, Reda, and Fuad Hasanov, 2019, "Principles of True Industrial Policy," Journal of Globalization and Development, De Gruyter, vol. 10(1), pages 1-22, June.

Ding, Xiaodan and Metodij Hadzi-Vaskov, 2017, "Composition of Trade in Latin America and the Caribbean," IMF Working Papers 2017/042, International Monetary Fund.

Eaton, Jonatahan and Samuel Kortum, 2002, "Technology, Geography, and Trade," Econometrica, Econometric Society, vol. 70(5), pages 1741-1779. 
Giri, Rahul, Saad N Quayyum, Rujun Yin, 2019, "Understanding Export Diversification:

Key Drivers and Policy Implications," IMF Working Papers 19/105, International Monetary Fund.

Haddad, Mona, Jamus Jerome Lim, Cosimo Pancaro and Christian Saborowski, 2012, "Trade openness reduces growth volatility when countries are well diversified," ECB Working Paper No. 1491.

Hallak, Juan Carlos, 2006, "Product Quality And The Direction Of Trade," Journal of International Economics, Vol 68 pp. 238-265.

Harrison, Ann and Andrés Rodríguez-Clare, 2010, "Trade, Foreign Investment, and Industrial Policy for Developing Countries," in Dani Rodrik and Mark Rosenzweig, editors: Handbook of Development Economics, Vol. 5, The Netherlands: North-Holland, 2010, pp. 4039-4214. ISBN: 978-0-444-52944-2

Hausman, Jerry A. and William E. Taylor, 1981, "Panel Data and Unobservable Individual Effects," Econometrica, Econometric Society, vol. 49(6), pages 1377-1398.

Hausmann, Ricardo, Jason Hwang and Dani Rodrik, 2006, "What You Export Matters," CEPR Discussion Papers 5444, C.E.P.R. Discussion Papers.

Hausmann, Ricardo, César A. Hidalgo, Sebastián Bustos, Michele Coscia, Alexander Simoes, Muhammed A. Yildirim, 2013, "The Atlas of Economic Complexity: Mapping Paths to Prosperity," The MIT Press.

Hidalgo, Cesar and Ricardo Hausmann, 2009, "The Building Blocks of Economic Complexity," Proceedings of the National Academy of Sciences of the United States of America, 106 (26), pp. 10570-10575.

Head, Keith, Tierry Mayer, and Jhon Ries, 2010, “The erosion of colonial trade linkages after independence," Journal of International Economics, 81(1):1-14, 2010.

Hnatkovska, Viktoria V. and Norman Loayza, 2004, "Volatility and growth," Policy Research Working Paper Series 3184, The World Bank.

International Monetary Fund, 1980, World Economic Outlook, Washington, D.C: International Monetary Fund.

International Monetary Fund, 2019, "Reigniting growth in low-income and emerging market economies: what role can structural reforms play," World Economic Outlook, Chapter 3, October. (Washington).

OECD, 2018, Trade in Value added. Available at http://www.oecd.org/sti/ind/measuringtrade-in-value-added.htm 
Polity IV, 2014, Polity IV Project, Severn, Maryland: Center for Systematic Peace. Retrieved from: http://www.systemicpeace.org/polity/polity4.htm.

Raei, Faezeh, Anna Ignatenko, Borislava Mircheva, 2019, "Global Value Chains: What are the Benefits and Why Do Countries Participate?," IMF Working Papers 2019/018, International Monetary Fund.

Ramey, Garey and Valerie A. Ramey, 1995, "Cross-Country Evidence on the Link Between Volatility and Growth," The American Economic Review, Vol. 85, No. 5 (Dec., 1995), pp. 1138-1151.

Rodrik, Dani, 2004, "Industrial Policy for the Twenty-First Century," CEPR Discussion Papers 4767, C.E.P.R. Discussion Papers.

Rodrik, Dani, 2008, "Normalizing Industrial Policy," World Bank Publications, The World Bank, number 28009, November.

Rose, Andrew K,2004, Do We Really Know That the WTO Increases Trade? American Economic Review, 94(1):98-114, 2004.

Sachs, Jeffrey and Andrew M. Warner 1995, "Economic reform and the process of global integration", Brookings Papers on Economic Activity, 1-118.

United Nations, 2020, UN Comtrade. Available at <http://comtrade.un.org $>$.

United Nations Development Program, 2020, Human Development Reports, Various editions, retrieved from: http://hdr.undp.org/en/content/education-index.

Wei, Shang-Jin, 1996, "Intra-national versus International Trade: How Stubborn Are Nation States in Globalization?”, NBER working papers no. 5331.

Wacziarg, Romain and Karen Horn Welch, 2008, "Trade Liberalization and Growth: New Evidence," World Bank Economic Review, World Bank Group, vol. 22(2), pages 187-231.

Weldemicael, Ermias O., 2012, "Determinants of Export Sophistication," The University of Melbourne, available at https://www.business.unsw.edu.au/About-Site/Schools-

Site/Economics-Site/Documents/E.Weldemicael\%20-

\%20Determinants $\% 20$ of $\% 20$ Export $\% 20$ Sophistication.pdf

World Bank, 2020a, Worldwide Governance Indicators, various editions, World Bank Publications, World Bank, Washington DC, retrieved from:

$<$ https://info.worldbank.org/governance/wgi/>.

World Bank, 2020b, World Integrated Trade Solution, various editions, World Bank, Washington DC, retrieved from: https://wits.worldbank.org/. 
World Bank, 2020c, Doing Business, various editions, World Bank Publications, The World Bank, Washington DC, retrieved from: https://www.doingbusiness.org/en/doingbusiness.

World Economic Forum, and Harvard University, 2020, The Global Competitiveness Report, various editions, Geneva: World Economic Forum, retrieved from:

https://www.weforum.org/reports/the-global-competitiveness-report-2020.

Yotov, Yoto, Roberta Piermartini, Jose Antonio Monteiro, and Mario. Larch, 2016, “An advanced guide to trade policy analysis: the structural gravity model," World Trade Organization. 
Table A.1: Determinants of Economic Complexity Index (ECI) and ECI Plus

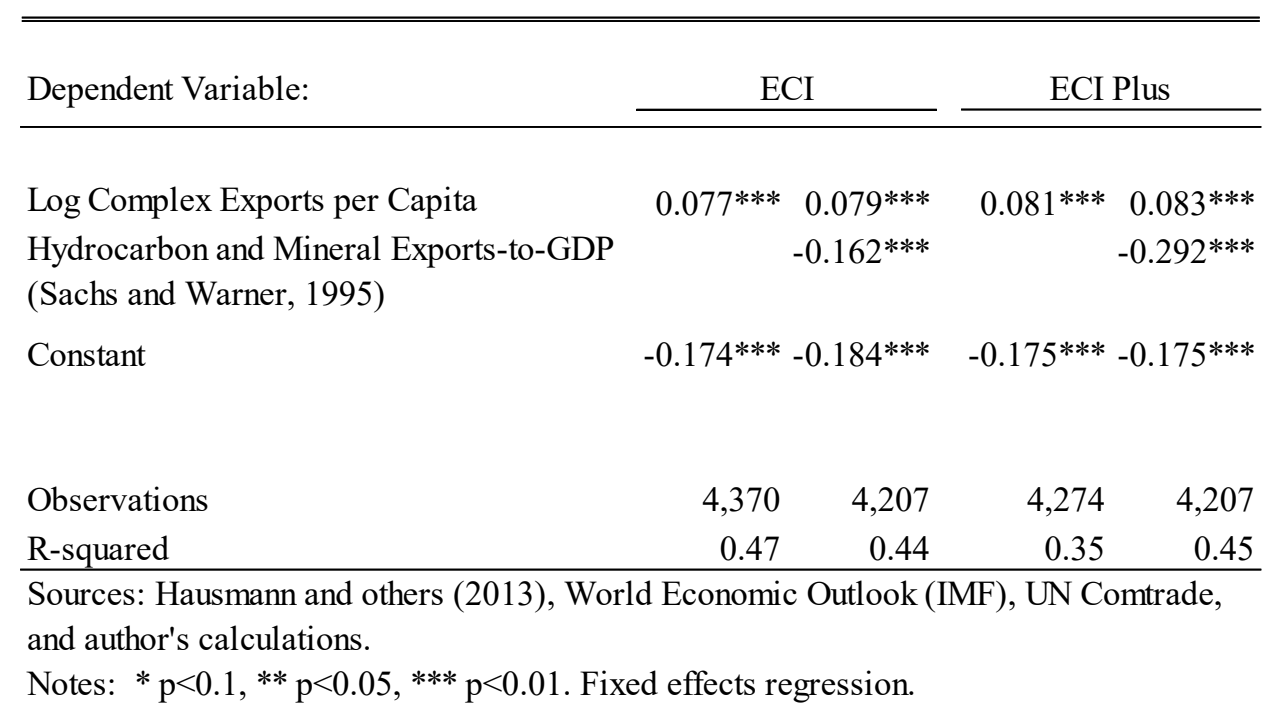


Table A.2: List of Countries by Regional Group

\begin{tabular}{|c|c|c|c|c|c|c|c|c|}
\hline Region & Region Code & Country & Region & Region Code & Country & Region & Region Code & Country \\
\hline \multirow[t]{5}{*}{ Andean } & \multirow[t]{5}{*}{ AND } & Bolivia & \multirow{23}{*}{$\begin{array}{l}\text { Eastern } \\
\text { Europe }\end{array}$} & \multirow[t]{23}{*}{$\mathrm{EE}$} & Albania & \multirow[t]{3}{*}{ Pacific Isl. } & \multirow[t]{3}{*}{ PAC } & Tonga \\
\hline & & Colombia & & & Bosnia Herz. & & & Tuvalu \\
\hline & & Ecuador & & & Bulgaria & & & Vanuatu \\
\hline & & Peru & & & Croatia & \multirow[t]{7}{*}{ South Asia } & \multirow[t]{2}{*}{ SAR } & Afghanistan \\
\hline & & Venezuela & & & Cyprus & & & Bangladesh \\
\hline \multirow[t]{8}{*}{ Arab } & \multirow[t]{8}{*}{ ARB } & Bahrain & & & Czechia & & & Bhutan \\
\hline & & Brunei & & & Estonia & & & Nepal \\
\hline & & Kuwait & & & Georgia & & & Pakistan \\
\hline & & Oman & & & Hungary & & & Sri Lanka \\
\hline & & Qatar & & & Latvia & & & Timor-Leste \\
\hline & & Saudi Arabia & & & Lithuania & Southern & $\mathrm{SCC}$ & Argentina \\
\hline & & UAE & & & Montenegro & Cone & & Brazil \\
\hline & & Yemen & & & N. Macedonia & & & Chile \\
\hline \multirow[t]{8}{*}{ Central Asia } & $\mathrm{CA}$ & Armenia & & & Poland & & & Paraguay \\
\hline & & Azerbaijan & & & Moldova & & & Uruguay \\
\hline & & Belarus & & & Romania & Scandinavia & $\mathrm{SCN}$ & Denmark \\
\hline & & Kazakhstan & & & Russia & & & Finland \\
\hline & & Kyrgyzstan & & & Serbia & & & Iceland \\
\hline & & Tajikistan & & & Serb. and Mont. & & & Norway \\
\hline & & Turkmenistan & & & Slovakia & & & Sweden \\
\hline & & Uzbekistan & & & Slovenia & Sub- & SSA & Angola \\
\hline Central Am. & CAM & Costa Rica & & & Turkey & Saharan & & Benin \\
\hline \& Mexico & & El Salvador & & & Ukraine & Africa & & Botswana \\
\hline & & Guatemala & European & EU & Andorra & & & Burkina Faso \\
\hline & & Honduras & Union & & Austria & & & Burundi \\
\hline & & Mexico & & & Belgium & & & Cabo Verde \\
\hline & & Nicaragua & & & France & & & Cameroon \\
\hline & & Panama & & & Germany & & & Central African Rep. \\
\hline Caribbean & CAR & Anguilla & & & Greece & & & Chad \\
\hline & & Antig. \& Barb. & & & Greenland & & & Comoros \\
\hline & & Aruba & & & Ireland & & & Congo \\
\hline & & Bahamas & & & Italy & & & Cote d'Ivoire \\
\hline & & Barbados & & & Luxembourg & & & D.R. Congo \\
\hline & & Belize & & & Malta & & & Djibouti \\
\hline & & Bermuda & & & Netherlands & & & Eritrea \\
\hline & & Cayman Isds & & & Portugal & & & Ethiopia \\
\hline & & Cuba & & & Spain & & & Gabon \\
\hline & & Dominica & & & Switzerland & & & Gambia \\
\hline & & Dominican Rep. & & & U.K & & & Ghana \\
\hline & & French Guiana & India & IND & India & & & Guinea \\
\hline & & Grenada & Middle East & ME & Iran & & & Guinea-Bissau \\
\hline & & Guadeloupe & & & Iraq & & & Kenya \\
\hline & & Guyana & & & Israel & & & Lesotho \\
\hline & & Haiti & & & Jordan & & & Liberia \\
\hline & & Jamaica & & & Lebanon & & & Madagascar \\
\hline & & Martinique & & & Syria & & & Malawi \\
\hline & & Montserrat & North Africa & NA & Algeria & & & Mali \\
\hline & & St. Kitts \& Nevis & & & Egypt & & & Mauritania \\
\hline & & Saint Lucia & & & Libya & & & Mauritius \\
\hline & & St. Vct. \& Gren. & & & Morocco & & & Mayotte \\
\hline & & Suriname & & & Tunisia & & & Mozambique \\
\hline & & Trinidad \& Tob. & North & NAM & Canada & & & Namibia \\
\hline East Asia & EAEM & China & America & & USA & & & Niger \\
\hline Emerging & & China, Macao SAR & Oceania & OCE & Australia & & & Nigeria \\
\hline & & Indonesia & & & New Zealand & & & Rwanda \\
\hline & & Malaysia & Pacific Isl. & PAC & Cook Isds & & & Sao Tome \& Princ. \\
\hline & & Philippines & & & FS Micronesia & & & Senegal \\
\hline & & Thailand & & & Faeroe Isds & & & Seychelles \\
\hline & & Viet Nam & & & Fiji & & & Sierra Leone \\
\hline East Asia & EAHI & China, Hong Kong & & & French Polynesia & & & Somalia \\
\hline High Income & & Japan & & & Kiribati & & & South Africa \\
\hline & & Singapore & & & Maldives & & & Sudan \\
\hline & & South Korea & & & New Caledonia & & & Togo \\
\hline East Asia & EAOTH & Cambodia & & & Palau & & & Uganda \\
\hline Others & & Lao PDR & & & Pap. New Gn. & & & Tanzania \\
\hline & & Mongolia & & & Samoa & & & Zambia \\
\hline & & Myanmar & & & Solomon Isds & & & Zimbabwe \\
\hline
\end{tabular}




\section{Panel Figure A.1: Index of Determinants of Economic Complexity}

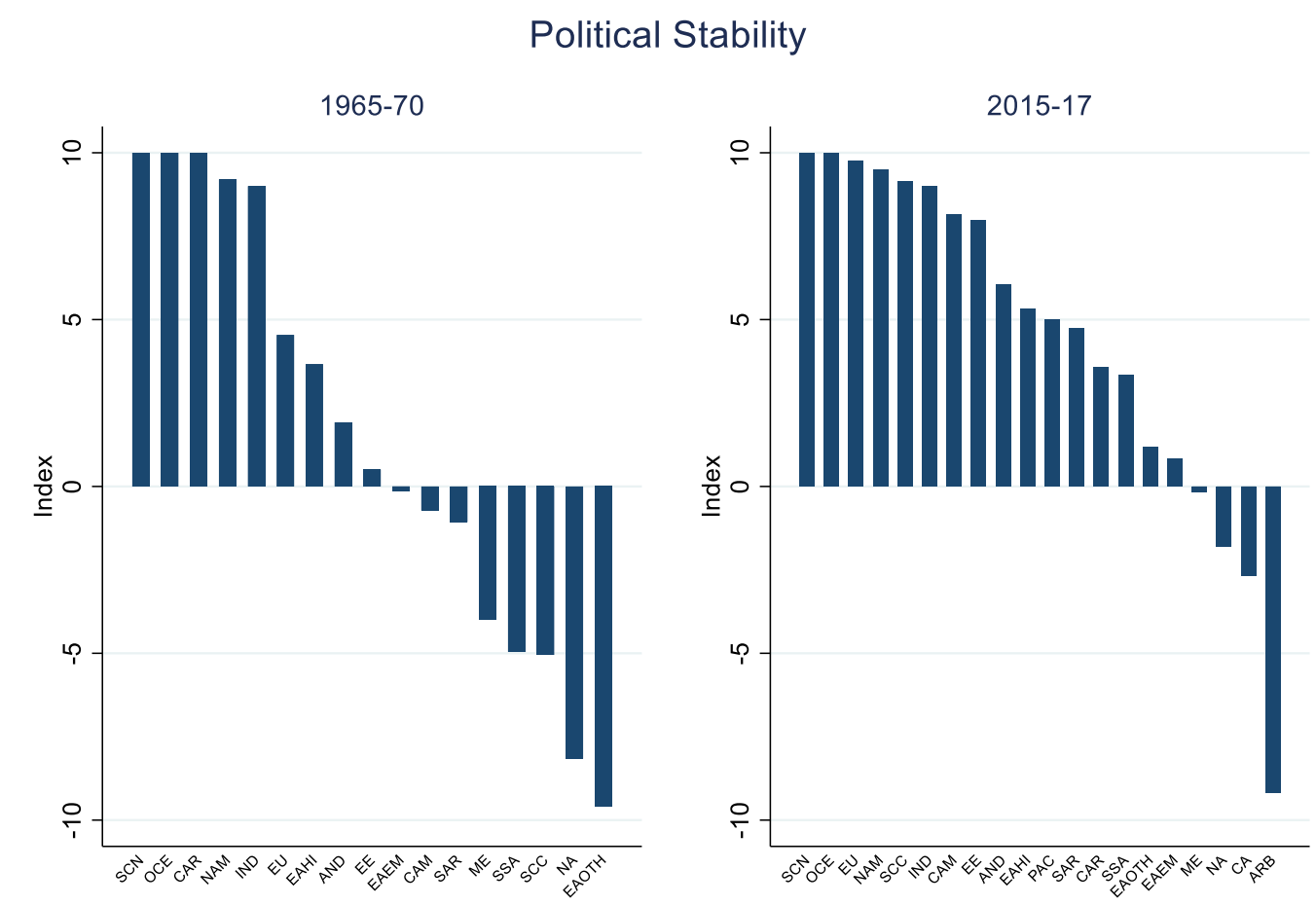

Source: Center for Systemic Peace, Polity IV dataset.

\section{Educational Attainment}
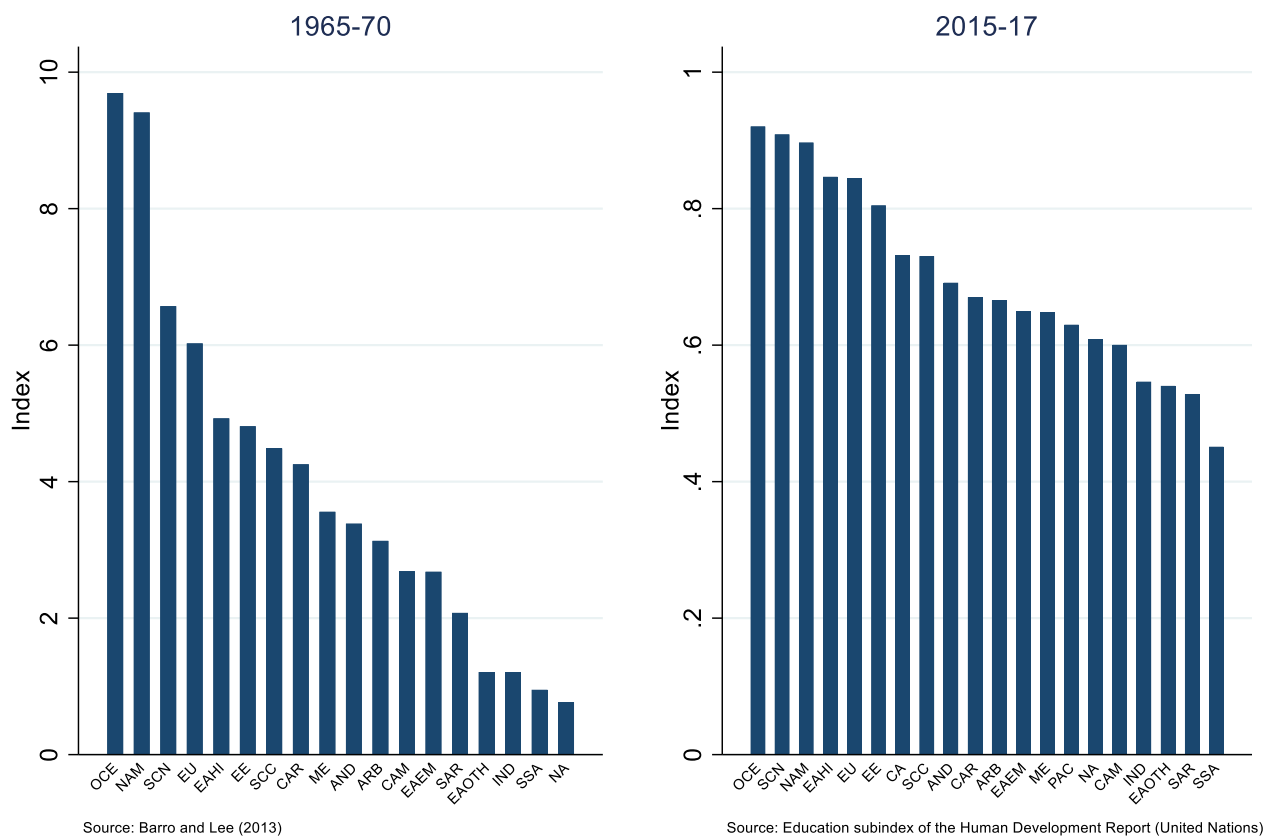

CInternational Monetary Fund. Not for Redistribution 


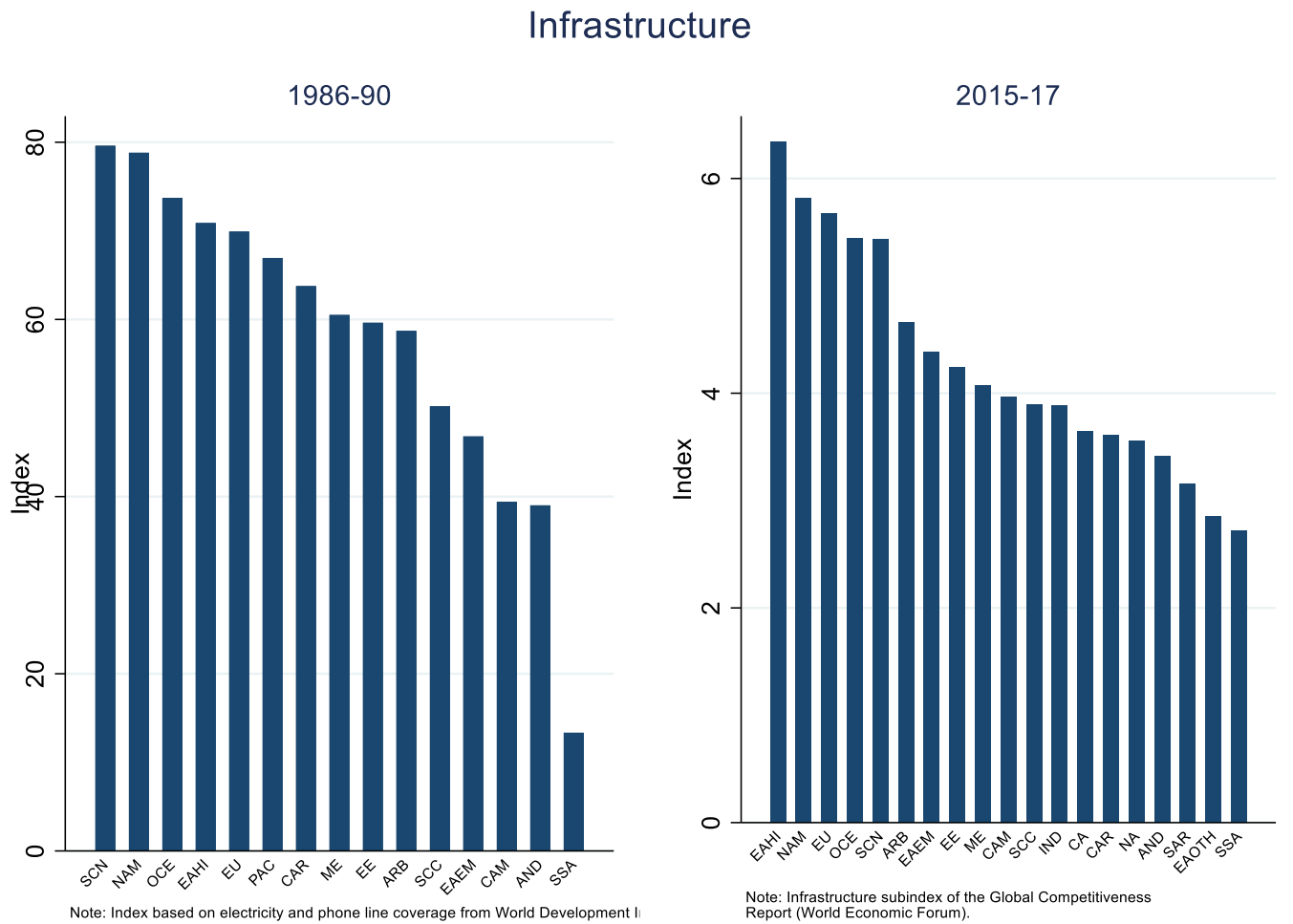

Average Imports Tariffs
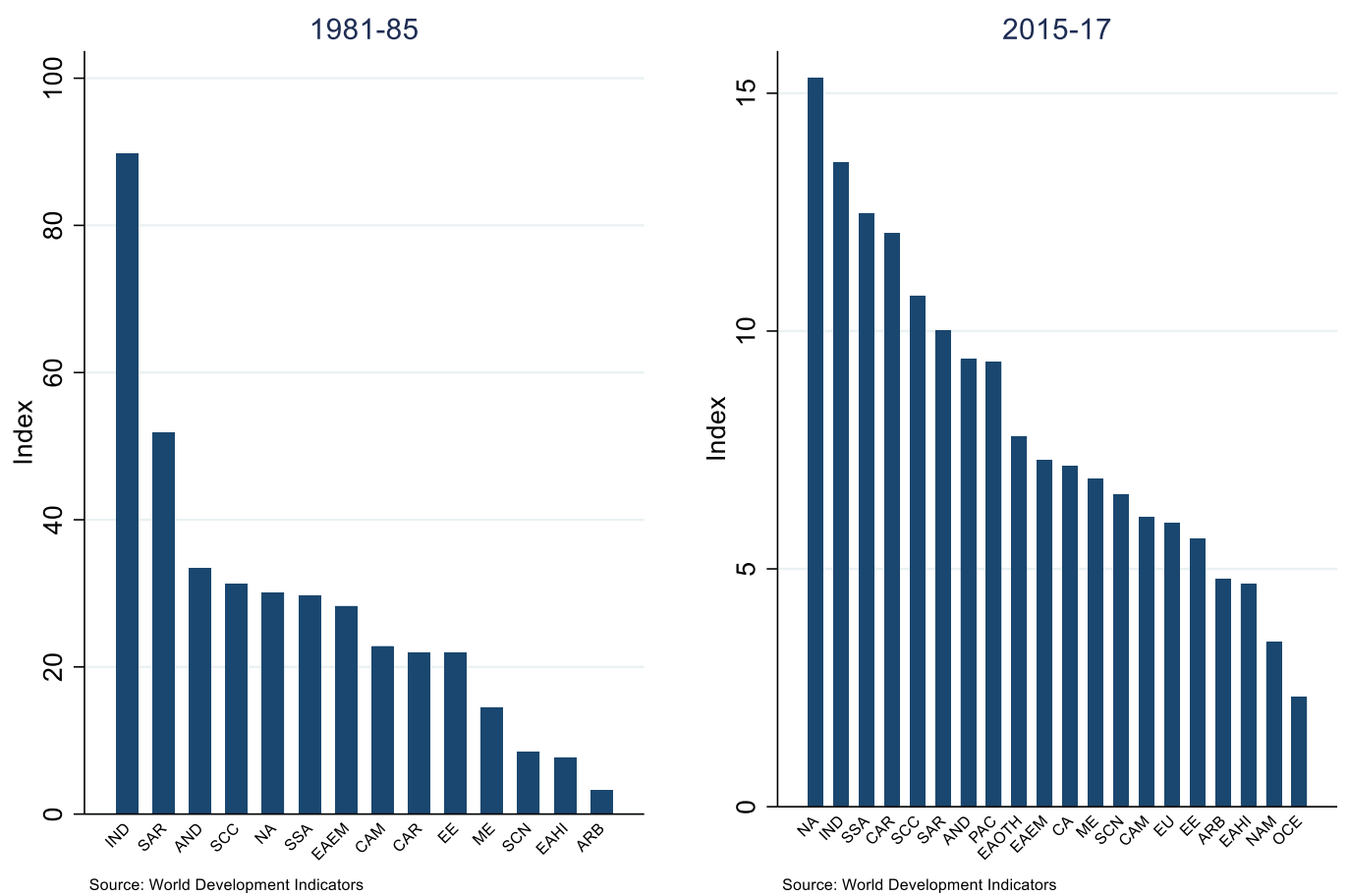

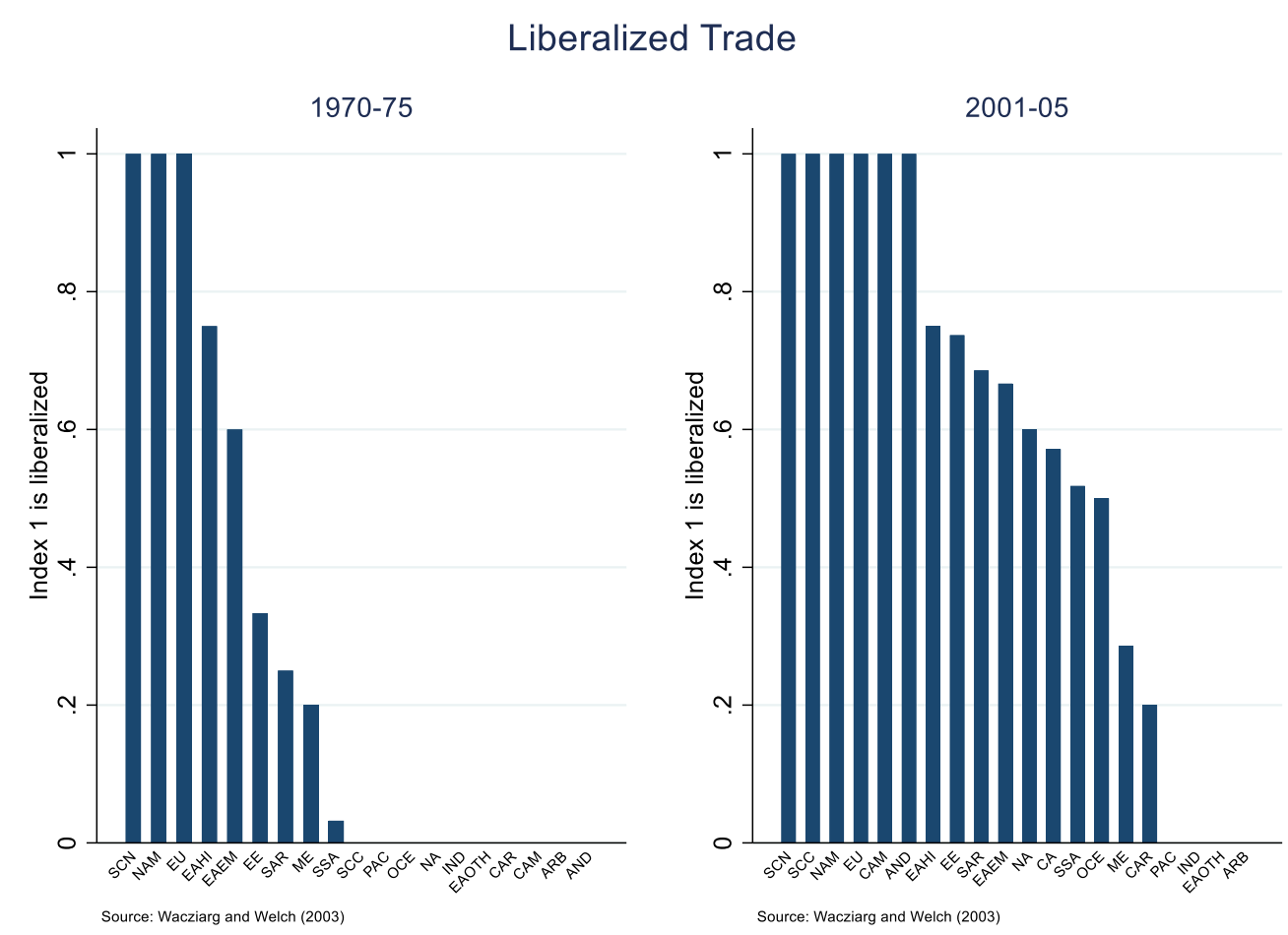
Table A.3: Determinants of exports by regression specification

\begin{tabular}{|c|c|c|c|c|c|c|c|}
\hline \multicolumn{8}{|c|}{ Dependent Variable: Log of non-hydrocarbon/mineral exports } \\
\hline Regression specification & $\begin{array}{l}\text { Hausman- } \\
\text { Taylor }\end{array}$ & $\begin{array}{l}\text { Hausman- } \\
\text { Taylor }\end{array}$ & $\begin{array}{l}\text { Hausman- } \\
\text { Taylor }\end{array}$ & Pooled OLS & $\begin{array}{c}\text { Between } \\
\text { Effects }\end{array}$ & $\begin{array}{l}\text { Random } \\
\text { Effects }\end{array}$ & Fixed Effects \\
\hline Log GDP reporter & $0.756 * * *$ & $0.484 * * *$ & $0.756^{* * *}$ & $1.354 * * *$ & $1.345 * * *$ & $1.369 * * *$ & $-0.548 * * *$ \\
\hline Log GDP partner & $0.858 * * *$ & $0.960 * * *$ & $0.858 * * *$ & $0.920 * * *$ & $0.904 * * *$ & $0.925 * * *$ & $0.347 * * *$ \\
\hline Log distance & $-1.279 * * *$ & $-0.616 * * *$ & $-1.279 * * *$ & $-1.420 * * *$ & $-1.444 * * *$ & $-1.465 * * *$ & \\
\hline Common currency dummy & 0.22 & $0.368^{* *}$ & 0.22 & $-0.193^{*}$ & -0.27 & -0.01 & \\
\hline Common border dummy & $1.888^{* * *}$ & $2.999 * * *$ & $1.888^{* * *}$ & $1.308 * * *$ & $1.327 * * *$ & $1.260 * * *$ & \\
\hline Common language dummy & $0.617 * * *$ & $0.899 * * *$ & $0.617 * * *$ & $0.676^{* * *}$ & $0.773 * * *$ & $0.638 * * *$ & \\
\hline Common colonizer dummy & $0.339 * *$ & $0.327 * *$ & $0.339 * *$ & $0.602 * * *$ & $0.561 * * *$ & $0.444 * * *$ & \\
\hline Past colonial link dummy & $1.228 * * *$ & $1.309 * * *$ & $1.228 * * *$ & $0.526^{* * *}$ & $0.482 * * *$ & $0.790 * * *$ & \\
\hline Log GDP per capita & -0.15 & -0.04 & -0.15 & $-0.918 * * *$ & $-0.973 * * *$ & $-0.680 * * *$ & $0.866^{* * *}$ \\
\hline Governance (WB Index) & $0.484 * * *$ & $0.422 * * *$ & $0.484 * * *$ & $0.634 * * *$ & $0.505 * * *$ & $0.789 * * *$ & $0.099 *$ \\
\hline Education (UN Index) & $5.099 * * *$ & $3.924 * * *$ & $5.099 * * *$ & $1.166^{* * *}$ & $1.498 * * *$ & $0.799 * * *$ & $1.031 * *$ \\
\hline Infrastructure (GCR Index) & $0.175^{* * *}$ & $0.166^{* * *}$ & $0.175^{* * *}$ & $0.694 * * *$ & $0.864 * * *$ & $0.307 * * *$ & $0.113 * * *$ \\
\hline Average Tariff & $-0.0310 * * *$ & $-0.0304 * * *$ & $-0.0310 * * *$ & $-0.0722 * * *$ & $-0.0784 * * *$ & $-0.0421 * * *$ & $-0.0197 * * *$ \\
\hline Labor market flexiblity (GCR Index) & 0.02 & 0.04 & 0.02 & $-0.334 * * *$ & $-0.374 * * *$ & -0.04 & 0.03 \\
\hline \multirow[t]{2}{*}{ Constant } & -0.86 & $-19.34 * * *$ & -0.86 & $-11.67 * * *$ & $-12.17 * * *$ & $-11.28 * * *$ & $-7.223 * *$ \\
\hline & $(-0.27)$ & $(-14.50)$ & $(-0.27)$ & $(-13.71)$ & $(-8.86)$ & $(-9.76)$ & $(-3.00)$ \\
\hline Partner country policy variables & No & Yes & Yes & Yes & Yes & Yes & Yes \\
\hline Multilateral resistance proxies & No & No & Yes & Yes & Yes & Yes & Yes \\
\hline Observations & 44,989 & 44,989 & 44,989 & 44,989 & 44,989 & 44,989 & 44,989 \\
\hline Rho & 0.93 & 0.94 & 0.93 & & & 0.81 & 0.94 \\
\hline $\begin{array}{l}\text { Notes: } * \mathrm{p}<0.1,{ }^{* *} \mathrm{p}<0.05, * * * \mathrm{p}<0.0 \\
\text { reporter and partner countries in UN C } \\
\text { data availability. Regression specifica } \\
\text { (coefficients not reported). Dependent } \\
2999,4000-6772,6900-8999 \text { ). }\end{array}$ & $\begin{array}{l}\text { based on } \mathrm{H} \\
\text { Observations } \\
\text { on (7). Mult } \\
\text { rithm of the }\end{array}$ & $\begin{array}{l}\text { Isman and } \mathrm{Ta} \\
\text { are non-overl } \\
\text { ateral resista } \\
\text { lue of expor }\end{array}$ & $\begin{array}{l}\text { aylor }(1981) \mathrm{t} \\
\text { lapping } 5 \text {-yea } \\
\text { nce terms anc } \\
\text { ts excluding } 1\end{array}$ & $\begin{array}{l}\text { ar averages } \\
\text { ad partner cou } \\
\text { hydrocarbon }\end{array}$ & $\begin{array}{l}\mathrm{n} \text { the } 1962 \\
y^{\prime} \text { s policy } \\
\text { mineral p }\end{array}$ & $\begin{array}{l}\text { ng of all com } \\
18 \text { period, de } \\
\text { ables include } \\
\text { acts (SITC2 }\end{array}$ & $\begin{array}{l}\text { mbinations of } \\
\text { epending on } \\
\text { ed } \\
\text { codes } 0 \text { - }\end{array}$ \\
\hline
\end{tabular}




\section{Panel Figure A.2: Actual vs Predicted Exports}

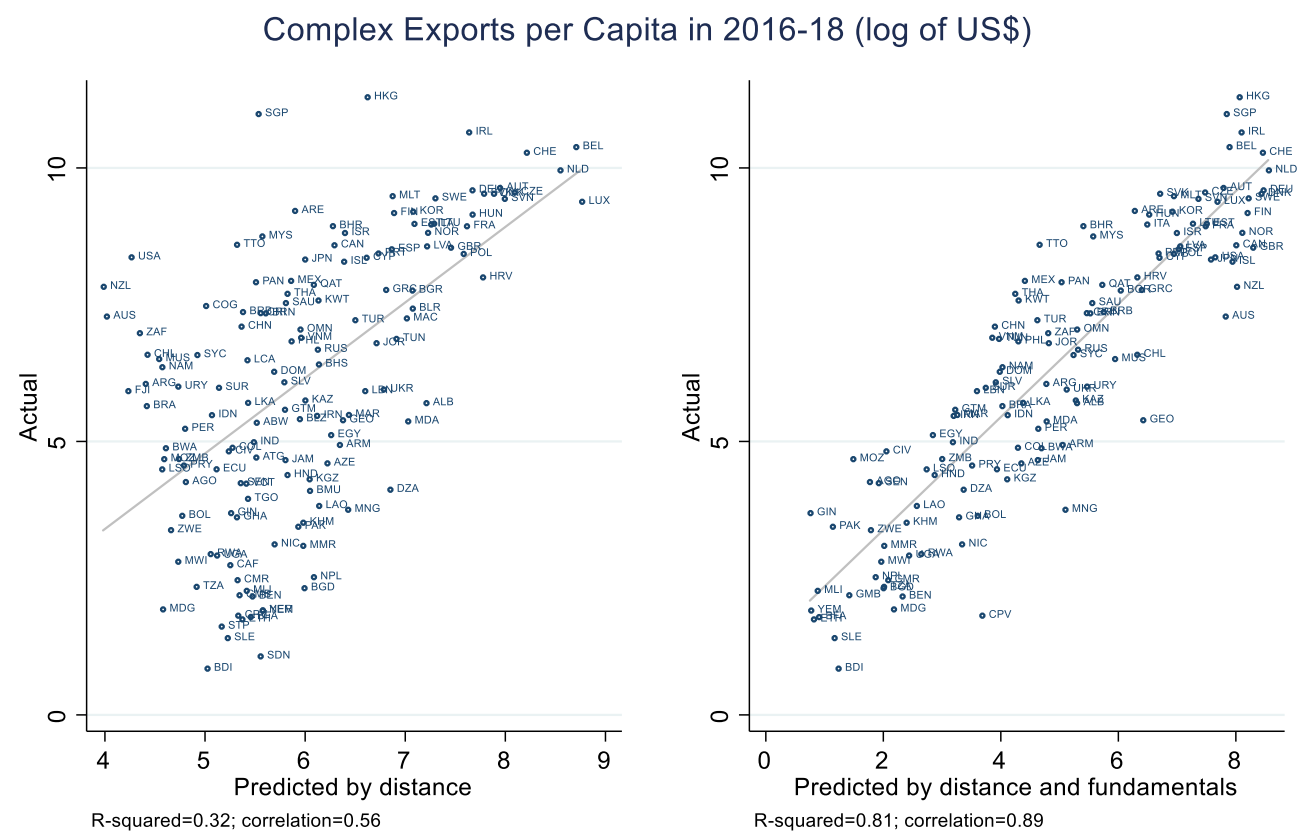

Source: UN COMTRADE and author's calculations.

Note: Complex exports are those with Product Complexity Index (Hausmann and others, 2013) above zero. Country codes from ISO 3 nomenclature.

Manufacturing exports per capita in 2016-18 (log of US\$)
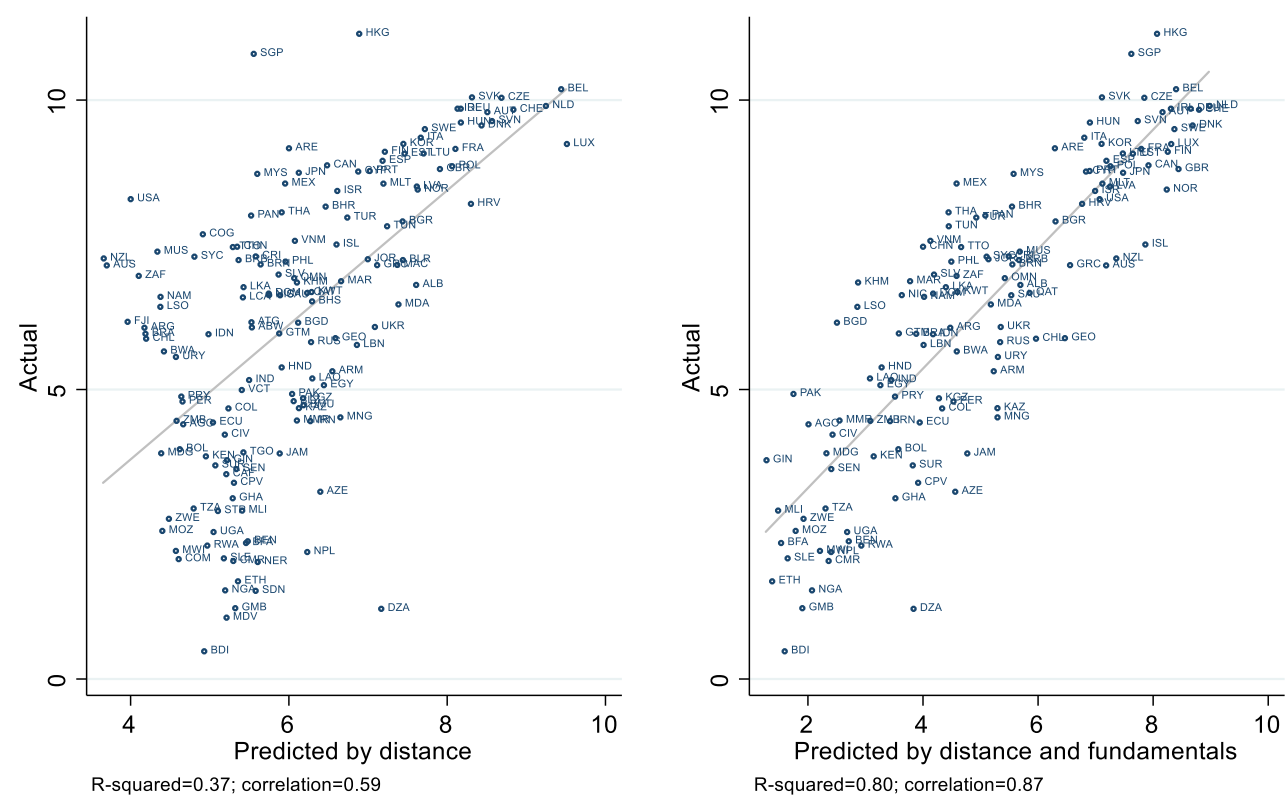

Source: UN COMTRADE and author's calculations.

Note: Exports SITC Rev2 from 6900 to 8999. Country codes from ISO 3 nomenclature. 
Service Exports per Capita in 2016-18 (log of US\$)
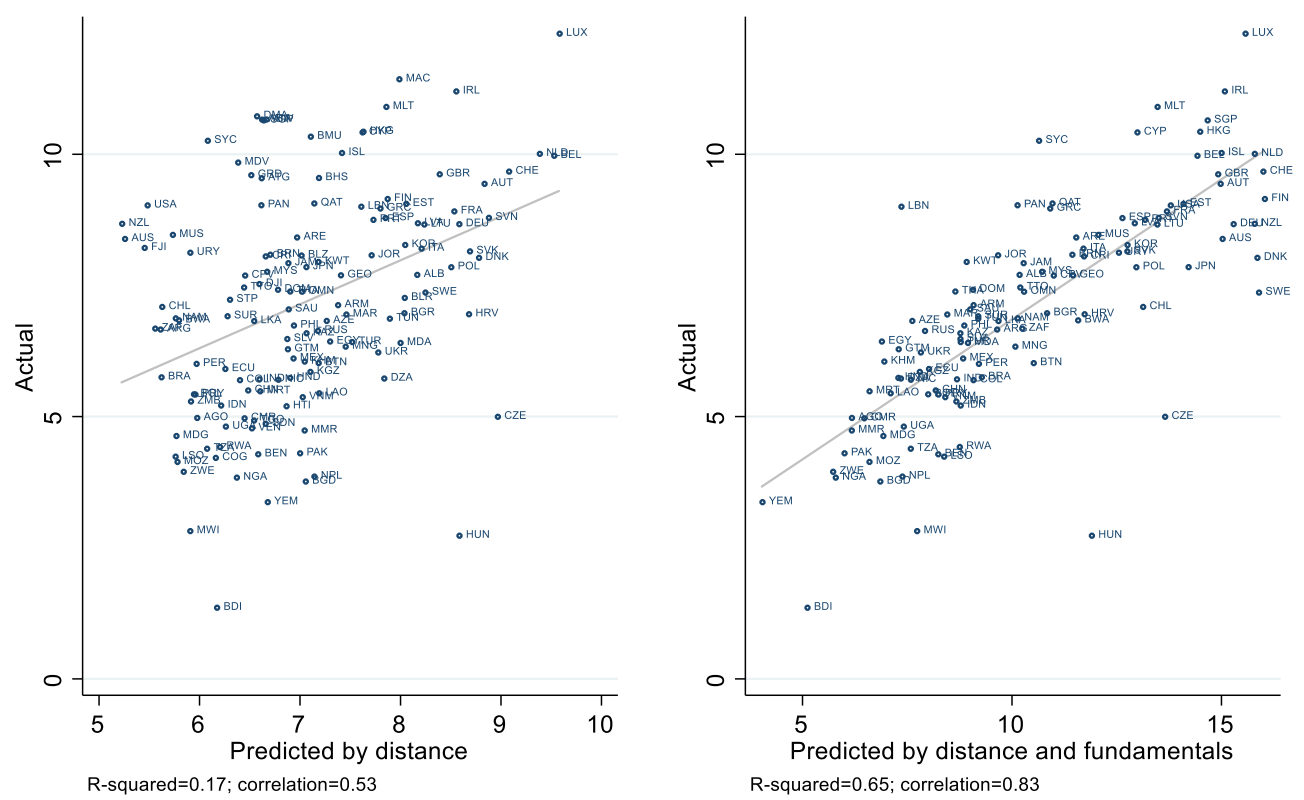

Source: UN COMTRADE and author's calculations. Note: Country codes from ISO 3 nomenclature.

Hydrocarbon and Mineral Exports per Capita in 2016-18 (log of US\$)
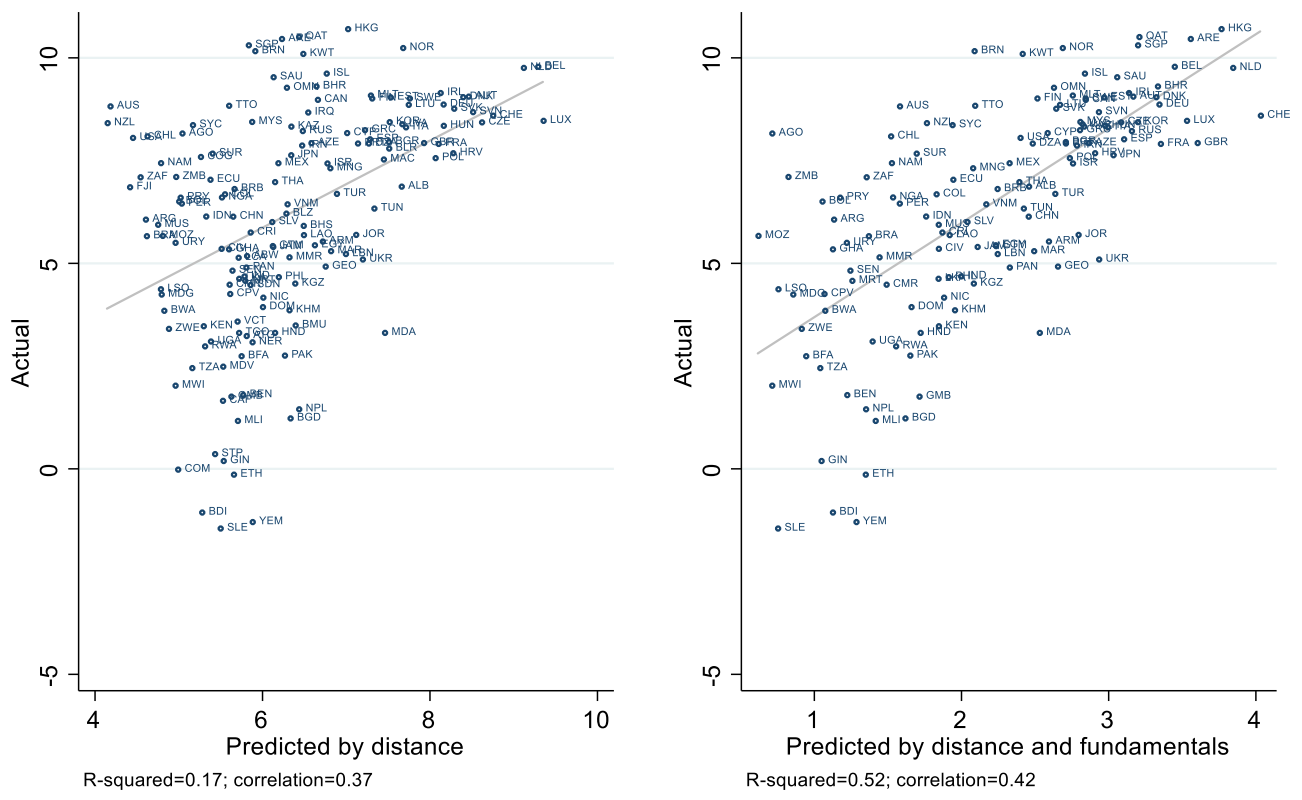

Source: UN comtrade and author's calculations. Note: Country codes from ISO 3 nomenclature. 

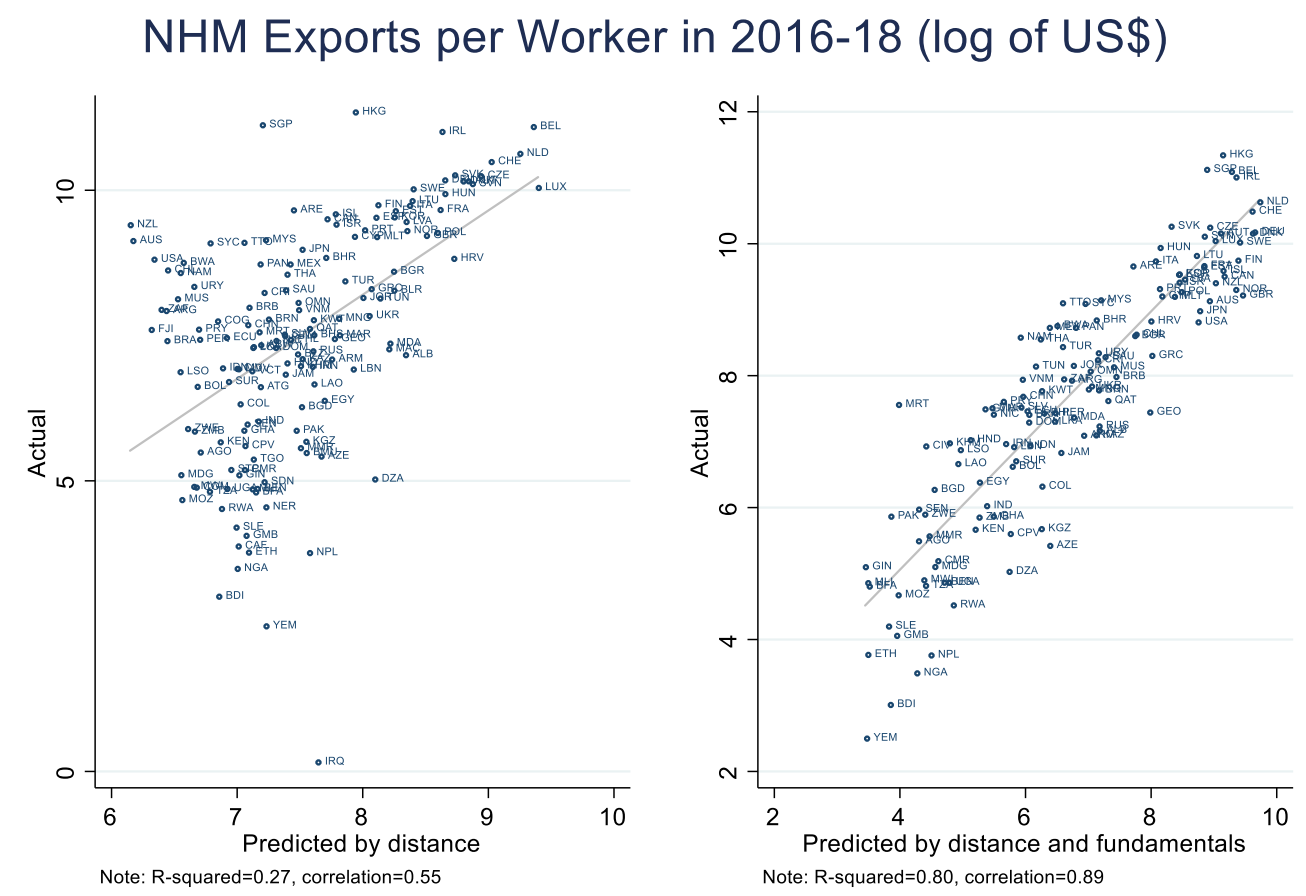

Source: UN Comtrade 
Panel Figure A.3: Deviation of Actual Exports from Predicted-by Distance Exports

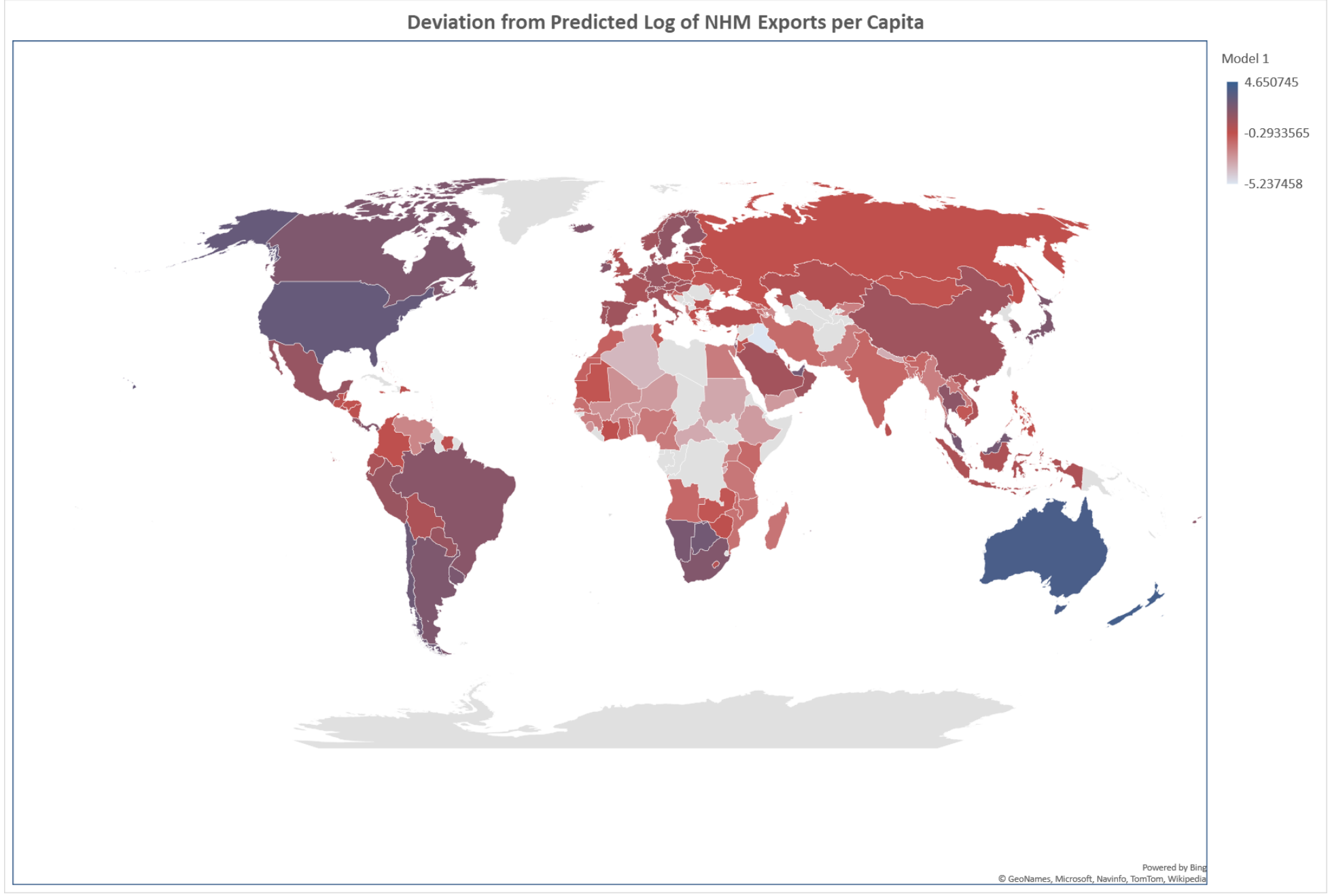




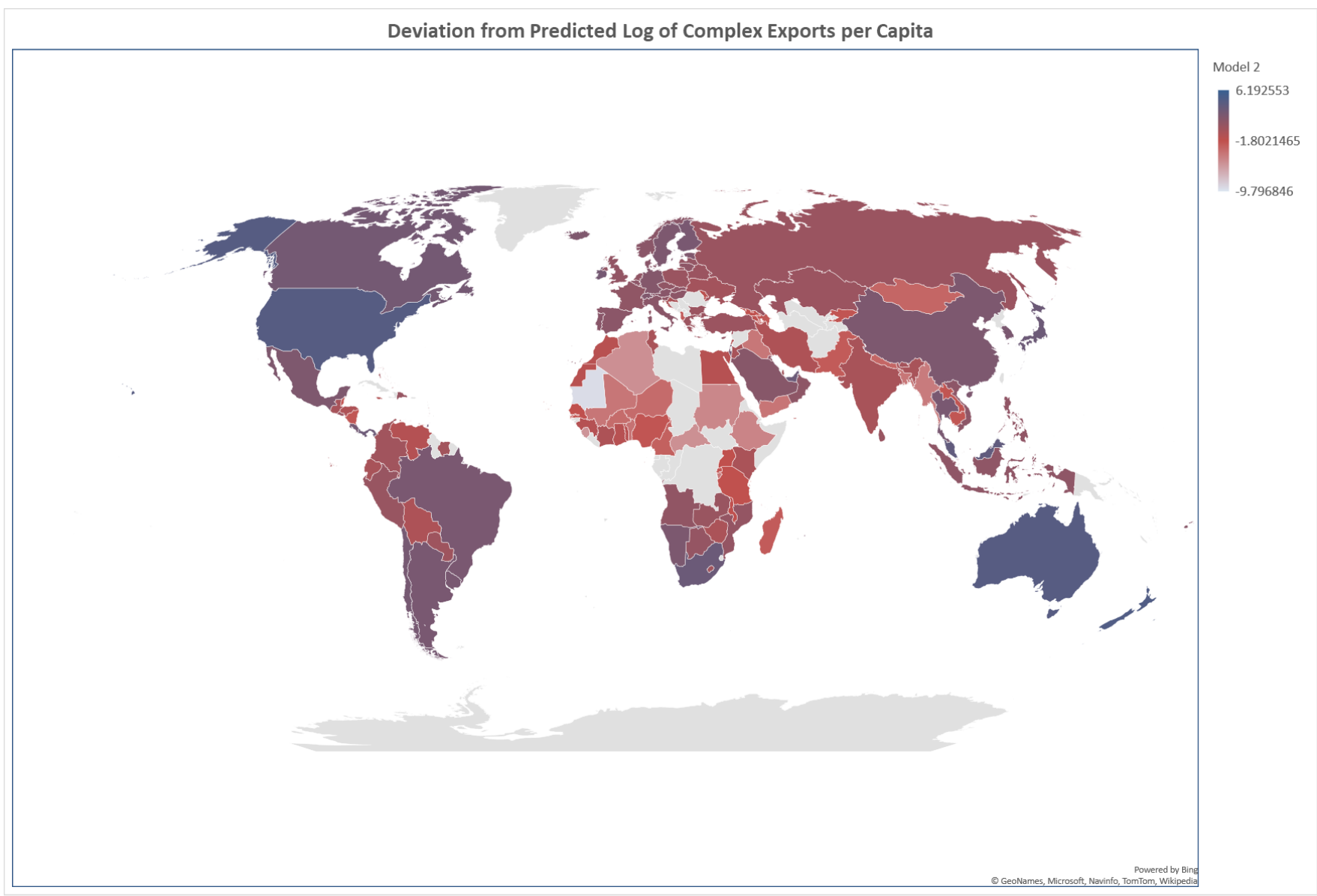


Panel Figure A.4: Distance and Fundamentals by Subregion in 2015-2017
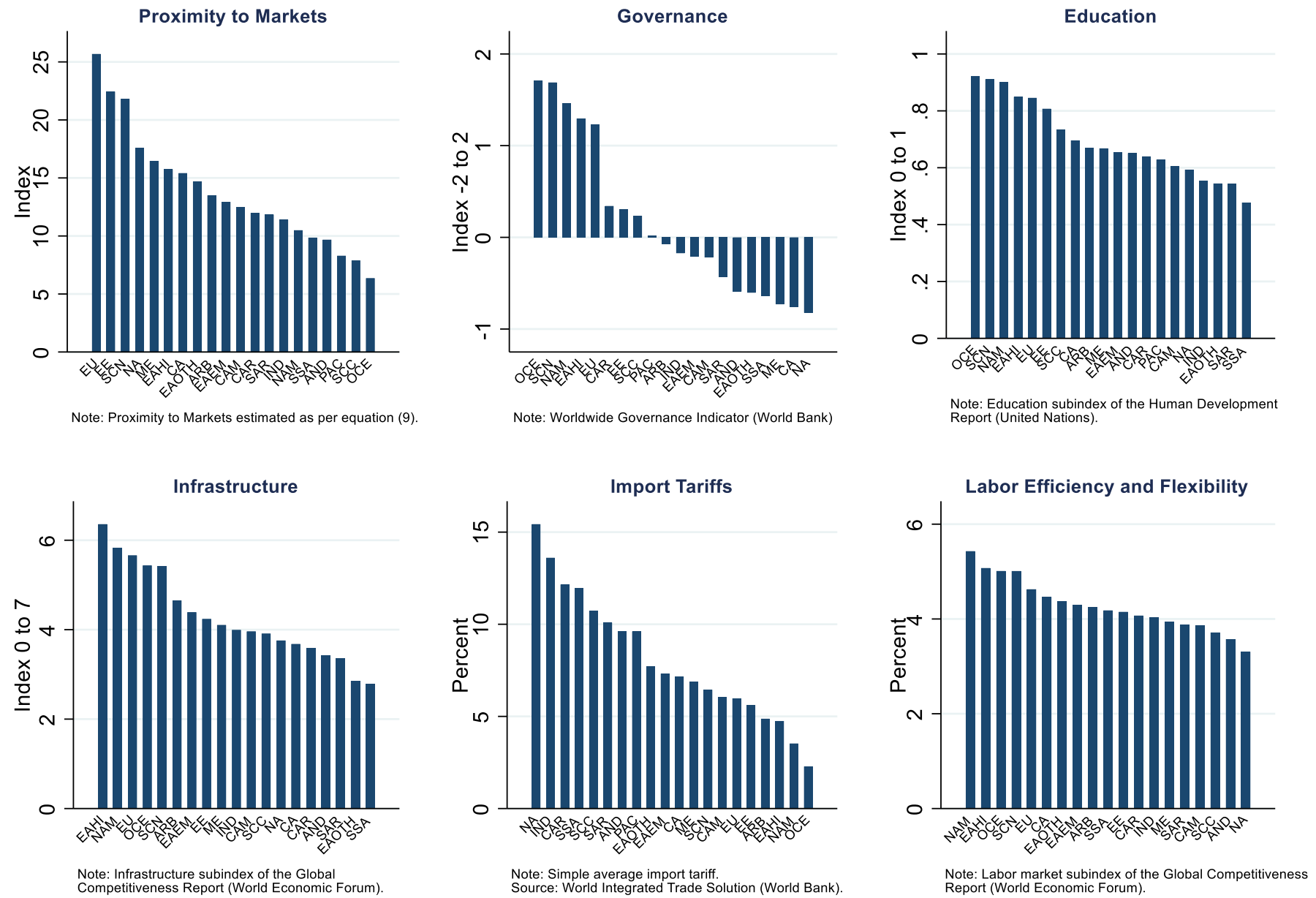
Panel Figure A.5: Other Explanatory Variables by Subregion in 2015-2017
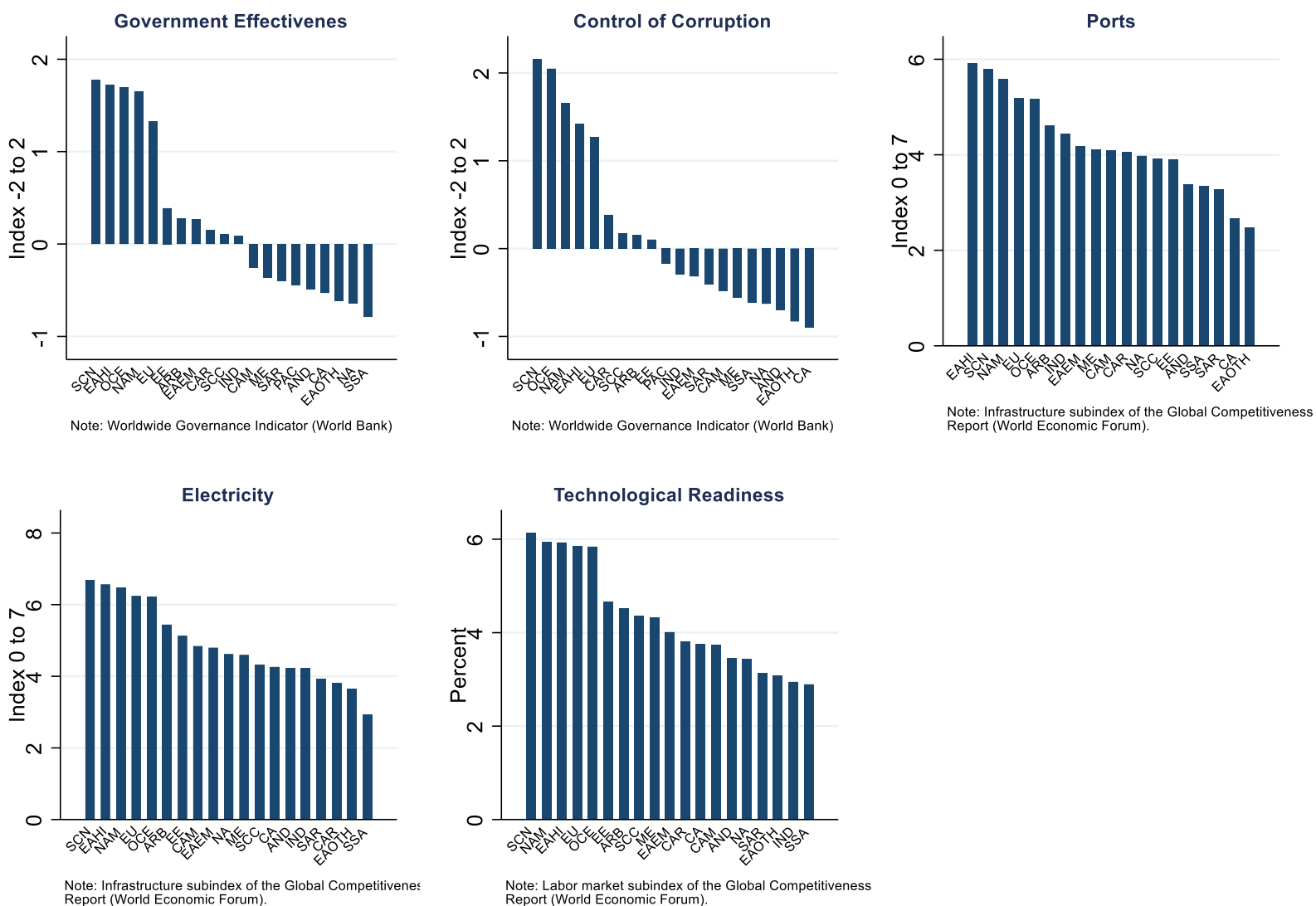
Table A.4: Summary Results by Study

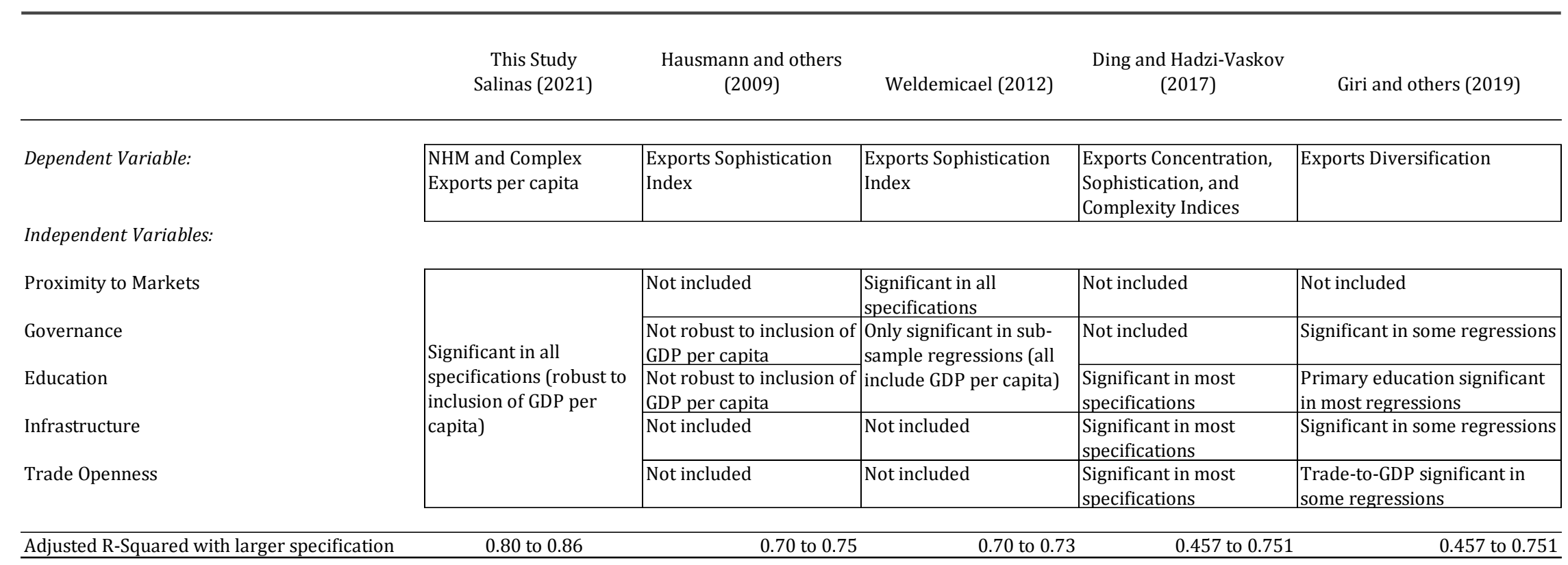

